\title{
In Vitro Cell Responses of MG-63 Osteoblast Cells on Bioactive Diopside and Wollastonite Nano- Bioceramics for Biomedical Applications
}

Ruhollah Zamani Foroushani

Dept. of Materials Engineering, IA Najafabad Branch

Ebrahim Karamian ( $\nabla$ ebkaramian91@gmail.com)

Advanced Materials Research Center, Dept. of Materials , IA Najafabad Branch, Isfahan- Iran

Mohammad Rafienia

Isfahan University of Medical Sciences

\section{Research Article}

Keywords: Bioactivity, Biomineralization, Cell responses, Cytotoxicity, Diopside, Wollastonite, Nanobioceramic

Posted Date: August 7th, 2020

DOl: https://doi.org/10.21203/rs.3.rs-52269/v1

License: (c) (i) This work is licensed under a Creative Commons Attribution 4.0 International License. Read Full License 


\title{
In vitro cell responses of MG-63 osteoblast cells on bioactive diopside and wollastonite nano-bioceramics for biomedical applications
}

\author{
Ruhollah Zamani Foroushani ${ }^{(1)}$ Ebrahim Karamian ${ }^{(1)}$, Mohammad Rafienia ${ }^{(2)}$ \\ (1) Advanced Materials Research Center, Department of Materials Engineering, Najafabad Branch, \\ (2) Islamic Azad University, Najafabad, Iran \\ (3) School of Advanced Technology in Medicine, Isfahan University of Medical Sciences, Isfahan, Iran \\ Corresponding Author: ebkaramian91@gmail.com
}

\begin{abstract}
The present study aimed to synthesize and characterize diopside $\left(\mathrm{CaMgSi}_{2} \mathrm{O}_{6}\right)$ and wollastonite $\left(\mathrm{CaSiO}_{3}\right)$ nano-bioceramics via a combination of mechano-chemical and calcination processes. In vitro biomineralization and cell responses of wollastonite and diopside were performed on simulated body fluid (SBF) and MG63 osteoblast cells. Results revealed proper tissue biomineralization of wollastonite and diopside through the generation of an apatite-like layer on the surface of nanobioceramics. Cell responses of wollastonite and diopside eventuated noncytotoxicity by MG-63 osteoblast cells, and their viability and cell proliferation were confirmed. Alizarin red staining of diopside and wollastonite evidenced great bioactivity and tissue biomineralization, and the ALP enzyme of diopside and wollastonite was enhanced in contact with the MG-63 osteoblast cells. Regarding the existence of $\mathrm{Mg}^{2+}$ in the calcium-silicate network and the stability network, diopside illustrated high biological and cell responses in comparison to wollastonite, and both of them were suggested as bioactive and biocompatible nano-bioceramics for biomedical applications.
\end{abstract}

Keywords: Bioactivity, Biomineralization, Cell responses, Cytotoxicity, Diopside, Wollastonite, Nano-bioceramic 


\section{Introduction}

Restoration of bone defects is a significant challenge in medical and biomedical sciences, and finding alternative materials for bone tissues is vital. Calcium silicates $\left(\mathrm{CaSiO}_{3}\right.$ and $\left.\mathrm{Ca}_{2} \mathrm{SiO}_{4}\right)$ and calcium silicate-based ceramics have become the principal focus in biomaterials [1, 2]. These materials have biological properties such as bioactivity and enhancement of cell interactions compared to traditional calcium phosphates like hydroxyapatite (HAp) or $\beta$ - tricalcium phosphate [3]. Therefore, they are promising candidates as bone graft materials. Moreover, incorporating metal atoms $(\mathrm{Mg}, \mathrm{Zn}$ and $\mathrm{Zr}$ ) into the crystalline structure of calcium silicates has improved their biological revenue [4-7]. In fact, silicate biomaterials including wollastonite and $\mathrm{Ca}-\mathrm{Si}-\mathrm{M}$ ternary ceramics $(\mathrm{M}=\mathrm{Ti}, \mathrm{Mg}$, $\mathrm{Zn}$ and $\mathrm{Zr}$ ) are the topic of many research projects for bone tissue restoration usages. A significant feature of silicate biomaterials is their ability to release the silicon $(\mathrm{Si})$ ion which persuades the growth and distinction of osteoblast cells to some extent [8-10]. Additionally, a precise study of $\mathrm{CaO}-\mathrm{SiO}_{2}$ ceramics showed their direct connection with bone. This study showed that ceramics including $\mathrm{CaO}$ and $\mathrm{SiO}_{2}$ have suitable bioactivity and connection power to bone [11].

Recently, extension of $\mathrm{CaO}-\mathrm{SiO}_{2}-\mathrm{MgO}$ ceramics with diopside $\left(\mathrm{CaMgSi}_{2} \mathrm{O}_{6}\right)$ topic has found special consideration in biomaterials applications, and diopside has currently been identified as a bioactive bioceramic. Nakajima et al. established the presence of magnesium $(\mathrm{Mg})$ in $\mathrm{CaO}-\mathrm{SiO}_{2}$ system by using diopside as a biomaterial and discovered that diopside can form apatite in the simulated body fluid (SBF) solution $[12,13]$.

Chemical composition of diopside is similar to akermanite $\left(\mathrm{Ca}_{2} \mathrm{MgSi}_{2} \mathrm{O}_{7}\right)$. However, it has a lower degradability rate compared with akermanite and 
wollastonite. Moreover, in the chemical composition of diopside, calcium atom is replaced by magnesium atom and the $\mathrm{Mg}-\mathrm{O}$ bond is developed.

Since the $\mathrm{Mg}-\mathrm{O}$ bonding energy is higher than that of the $\mathrm{Ca}-\mathrm{O}$ bonding, the stability of the crystalline structure is increased [14]. On the other hand, the $\mathrm{CaO}-$ $\mathrm{SiO}_{2}-\mathrm{MgO}$ ceramic systems are appropriate for bone regeneration applications [15].

Duchin et al. found that the mechanism of bioactivity of $\mathrm{CaO}-\mathrm{SiO}_{2}-\mathrm{MgO}$ system ceramics is similar to silicate glass, which is related to the direct release of the $\mathrm{Si}$ ions [16]. One of the significant bioceramic compounds is wollastonite $\left(\mathrm{CaSiO}_{3}\right)$, which has unique characteristics such as thermal stability and high hardness. Hence, it has acquired abundant applications in ceramic industry [17]. In addition, wollastonite has high bioactivity so that apatite layers appear on it and grow fast only after 3 days. Besides, the growth rate of the hydroxyapatite in nanostructured wollastonite was more than its growth rate in micro-structured wollastonite [18].

One of the most interesting synthesis processes of nano-structured bio-ceramics is mechano-chemical process. The particle sizes of nano-structured materials are less than $100 \mathrm{~nm}$ [19]. Due to their ideal physical and chemical properties, they attract much attention of scientific and research communities [20].

In this study, in vitro cell responses of MG-63 osteoblast cells and biomineralization on synthesized diopside $\left(\mathrm{CaMgSi}_{2} \mathrm{O}_{6}\right)$ and wollastonite $\left(\mathrm{CaSiO}_{3}\right)$ nano-bioceramics via a combination of mechano-chemical and calcination processes were studied for biomedical applications.

\section{Materials and methods}

\subsection{Raw materials}


Calcium carbonate powder $\left(\mathrm{CaCO}_{3}\right)$ (Merck, Germany), silica $\left(\mathrm{SiO}_{2}\right)(\mathrm{Merck}$ Co., Germany) and magnesium oxide ( $\mathrm{MgO})$ (Merck Co., Germany) were used to synthesize diopside and wollastonite compounds.

\subsection{Synthesis of diopside and wollastonite}

To synthesize diopside, $15.38 \%$ wt of $\mathrm{MgO}, 46.15 \%$ wt of $\mathrm{SiO}_{2}$, and $38.46 \%$ wt of $\mathrm{CaCO}_{3}$ were chosen, and then mechano-chemical process (ball milling) was carried out. In this process, ball - to - powder weight ratio and milling speed were 10:1 and $350 \mathrm{rpm}$, respectively, and the milling times were 5 minutes, 10 and $20 \mathrm{~h}$. Then, the developed powders were calcinated at $1200^{\circ} \mathrm{C}$ for $2 \mathrm{~h} \mathrm{[21].}$

Similarly, the process was conducted to synthesize wollastonite, and the milling times were $5 \mathrm{~min}, 10$ and $20 \mathrm{~h}$. The raw materials included $37.5 \%$ wt of $\mathrm{SiO}_{2}$, $62.5 \%$ wt of $\mathrm{CaCO}_{3}$, and the molar ratio was 1.125 . The milling speed and ball - to - powder weight ratio were $350 \mathrm{rpm}$ and 10:1, respectively. After this process, the milled powders were calcinated at $1200^{\circ} \mathrm{C}$ for $2 \mathrm{~h}[21]$.

Fig. 1 depicts the mechanism of synthesis of the wollastonite and dopside nanobioceramics.

\subsection{Characterization of diopside and wollastonite}

To evaluate the phase structure of the milled and calcinated powders, XRD patterns of these samples were prepared using a PW3040 Philips X-ray diffractometer. The XRD patterns of the samples were obtained via $\mathrm{Cu}-\mathrm{k} \alpha$ radiation with a wavelength $\lambda=1.54018 A^{\circ}$ in the ranges of $15-70,10-60$ and 10 - 50 degrees. To determine the crystallites size of the developed compounds, the width of the present peaks was used in the XRD patterns and Scherrer method. The Scherrer equation is [22]:

(1) $\beta \operatorname{Cos} \theta=\frac{K \lambda}{D}$ 
Where $\mathrm{D}$ is the crystallite size, $\lambda$ is the wavelength, $\mathrm{K}$ is the shape factor (about 1 ), $\beta$ is the full width at half maximum (FWHM), and $\theta$ is half the diffraction angle.

To investigate the morphology and micro-structure of the synthesized diopside and wollastonite, SEM images were prepared using scanning electron microscopy (FEI, Quanta, USA). To examine the chemical composition and distribution of elements of the synthesized diopside and wollastonite compounds, EDS and X-ray map analyses were prepared. To examine the micro-structure and nano-structure of the synthesized diopside and wollastonite, TEM images of the samples were prepared using transmission electron microscopy (EM 208, Philips, the Netherlands).

\subsection{Biomineralization and cell responses}

The evaluation of biomineralization and formation of an apatite-like layer on the diopside and wollastonite nano-bioceramics surface was conducted via SBF solution provided according to the Kokubo method [23]. The nano-bioceramic samples were immersed in $25 \mathrm{ml}$ of the SBF solution $(\mathrm{pH}=7.4)$ and put into an incubator at $37^{\circ} \mathrm{C}$ for 28 days. After the immersion of the scaffolds for this period, they were washed with distilled water and dried in an oven at $50{ }^{\circ} \mathrm{C}$ for $48 \mathrm{~h}$.

The cytotoxicity evaluation was conducted according to ISO 10993-5 standard. The sterilization of the wollastonite and diopside particles was performed in an autoclave. Subsequently, the particles were immersed in Dulbecco's modified eagle medium (DMEM) culture medium using ultrasonic irradiation for $30 \mathrm{~min}$. The MG-63 osteoblast cells (6000 cells) were put into a $24-w e l l$ plate (TCPS or tissue culture polystyrene) in contact with the culture medium containing the wollastonite and diopside particles. To investigate the cell viability, MTT assay was conducted at 1, 3 and 7 days. Then, the medium was washed with PBS solution, and about $400 \mu \mathrm{l}$ of the medium and $40 \mu \mathrm{l}$ of the MTT solutions (5 $\mathrm{mg} / \mathrm{ml}$ ) were added to the culture well, which was kept in an incubator at $37{ }^{\circ} \mathrm{C}$ for $240 \mathrm{~min}$. The medium was evacuated so that the formazan could be dissolved, and 
$200 \mu 1$ of dimethyl sulfoxide (DMSO) was added to the wells. Optical absorption was evaluated over $570 \mathrm{~nm}$.

To examine the deposited calcium rate by the MG-63 osteoblast cells, alizarin red staining was used for 7 and 14 days. After culturing the MG-63 osteoblast cells for 7 and 14 days, the cells were fixed by formaldehyde (4\%) and then the prepared alizarin red staining (1\%) was added to Tris buffer solution with $\mathrm{pH}=8$ for $15 \mathrm{~min}$. The well plate containing cells was washed by PBS solution several times.

To investigate the alkaline phosphatase enzyme activity rate at 3, 7 and 14 days of cell culture on the diopside and wollastonite compounds, at first, the Ripa solution was used in the entire protein extraction. After extracting perfect cell culture, $20 \mu \mathrm{l}$ of the Ripa solution was poured on the bioceramics, and they were pipetted for 10 min. The Ripa solution was centrifuged with $14000 \mathrm{rpm}$ for $10 \mathrm{~min}$ and was kept at $4{ }^{\circ} \mathrm{C}$. Afterwards, for each $20 \mu \mathrm{l}$ of Ripa solution, $1 \mathrm{mM}$ of reagent No.1 of business kit of alkaline phosphatase was added to the samples, and they were put into the incubator at $37^{\circ} \mathrm{C}$ for 1 minute. Then, $250 \mu \mathrm{l}$ of reagent No. 2 was added to the samples, and the same process was repeated. After 1, 2 and 3 min, optical absorption was read over $405 \mathrm{~nm}$, and then its difference was determined from the last minute. Finally, these three differences and also their mean were calculated, and the final number was multiplied by factor 3433 .

\subsection{Statistical analysis}

The experiments were performed for $n=3$. All data were suggested as mean $\pm S D$. One-way analysis of variance (ANOVA) was used to compare the results. A pvalue of less than 0.05 was determined statistically significant.

\section{Results and discussion}

Figs. 2(a-c present the XRD patterns of the milled powders of materials like $\mathrm{MgO}$, $\mathrm{CaCO}_{3}$ and $\mathrm{SiO}_{2}$ at $5 \mathrm{~min}, 10 \mathrm{~h}$ and $20 \mathrm{~h}$. In Fig. 2(a), the milled powers at $5 \mathrm{~min}$, 
only magnesium oxide (MgO) (JCPDS 01 - 087 - 0652) and calcium carbonate $\left(\mathrm{CaCO}_{3}\right)$ phase (JCPDS $01-081$ - 2027) were observed, and by extending the milling time for $10 \mathrm{~h}$ (Fig. 2(b)), the peaks widened. This phenomenon is due to the decrease in the crystallite size and the increase in the lattice strain during the mechano-chemical process. By extending the milling time for $20 \mathrm{~h}$, because the raw materials became amorphous, the peaks related to calcium carbonate phase gradually decreased (Fig. 2(c), milling time $=20 \mathrm{~h}$ ). In the mechano-chemical (ball milling) process, much energy is applied to the powder particles and internal energy $(\Delta U)$ is highly increased. A lot of strains in the system present serious motion of dislocations causing different structural defects like dislocations, vacancies, stacking fault and increasing the development of grains boundary. Finally, these changes increase the speed of the reactions between the milled particles. Transformation of the milled powder structure is so high that the primary lattice is perfectly altered. During the milling process, various phenomena like mixing and chemical reaction in contact with particle levels and so on might occur, causing chemical reactions to take place during the milling process and reactivity of the milled product to increase [24].

The main peaks of $\mathrm{SiO}_{2}$ phase are not identifiable in the ranges of diffracted angles of 20 - 30 degrees in the XRD patterns (Figs. 2(a-c)). As a result of the milling process for $20 \mathrm{~h}$ (Fig. 2(c)), the pattern lacked the diopside phase $\left(\mathrm{CaMgSi}_{2} \mathrm{O}_{6}\right)$. Subsequently, to develop the diopside phase, the milled powders were calcinated at $1200{ }^{\circ} \mathrm{C}$ for $2 \mathrm{~h}$.

Figs. 2(d-f) present the XRD patterns of the calcination process of the milled powders at $5 \mathrm{~min}, 10 \mathrm{~h}$ and $20 \mathrm{~h}$ at $1200^{\circ} \mathrm{C}$. In the calcinated sample of the milled powder at $5 \mathrm{~min}(\mathrm{Fig} .1(\mathrm{~d}))$, the diopside $\left(\mathrm{CaMgSi}_{2} \mathrm{O}_{6}\right)$ phase (JCPDS $01-071-$ $1494)$ with mono-clinic structure was developed, and akermanite $\left(\mathrm{Ca}_{2} \mathrm{MgSi}_{2} \mathrm{O}_{7}\right)$ 
phase (JCPDS $01-077-1149$ ) with a tetragonal structure was observed in the XRD pattern of this sample (Fig. 2(d)).

In the calcinated sample of the milled powder at $10 \mathrm{~h}$ (Fig. 2(e)), the peaks related to the diopside phase increased, and those related to the akermanite phase decreased (Fig. 2(e)). In the calcinated sample of the milled powder at $20 \mathrm{~h}$ (Fig 2. (f)), the pattern lacked the akermanite phase, and only the diopside phase was clearly observed because of appropriate milling time $(20 \mathrm{~h})$ among the raw materials. Formation of the diopside phase is according to relations 2 and 3:

$\mathrm{CaCO}_{3} \rightarrow \mathrm{CaO}+\mathrm{CO}_{2}$

$\mathrm{CaO}+2 \mathrm{SiO}_{2}+\mathrm{MgO} \rightarrow \mathrm{CaMgSi}_{2} \mathrm{O}_{6}$

To obtain the optimum milling time, the milling process was conducted among raw materials like $\mathrm{CaCO}_{3}$ and $\mathrm{SiO}_{2}$ for 5 min and 10 and 20 h. Figs. 3(a-c) present the XRD patterns related to the milled powders at $5 \mathrm{~min}, 10$ and $20 \mathrm{~h}$. In the XRD pattern in Fig. 3(a), only the phases related to the raw materials like $\mathrm{CaCO}_{3}$ exist, and by increasing the milling time to $10 \mathrm{~h}$, the peaks widen (Fig. 3(b)) because of decreasing of the crystallite size and increasing of the lattice strain during the milling process [25]. In this pattern (Fig. 3(b)), only the phase related to the raw materials compound was observed. By increasing the milling time to $20 \mathrm{~h}$ (Fig. $3(\mathrm{c})$ ), because the raw materials became amorphous, some peaks related to $\mathrm{CaCO}_{3}$ phase were gradually removed and $20-30$ degrees increased. The main peaks of the $\mathrm{SiO}_{2}$ phase were in the diffracted angles of $20-30$ degrees, which was not identifiable in the XRD patterns (Figs. 3(a-c). The patterns lacked the wollastonite phase. Figs. 3(d-f) present the XRD patterns of the calcination process of the milled powders ( 5 min, 10 and $20 \mathrm{~h}$ of the milling time) at $120{ }^{\circ} \mathrm{C}$.

In Figs. 3(d, e), the wollastonite $\left(\mathrm{CaSiO}_{3}\right)$ phase and rankinite phase $\left(\mathrm{Ca}_{3} \mathrm{Si}_{2} \mathrm{O}_{7}\right)$ were observed because of extending the milling time to 20 hamong the raw materials. Formation of the wollastonite phase is according to relations 2 and 4 . 


$$
\mathrm{CaO}+\mathrm{SiO}_{2} \rightarrow \mathrm{CaSiO}_{3}
$$

To calculate the crystallite size of the synthesized diopside and wollastonite, the Scherrer method was used. Tables 1 and 2 present the calculated values for the synthesized diopside and wollastonite obtained by calcination and mechanochemical processes (milling time: $20 \mathrm{~h}$ ). According to the results, the mean crystallite sizes of diopside and wollastonite nano-bioceramics were 46 and $51 \mathrm{~nm}$, respectively.

Fig. 4(a) presents the morphology related to the synthesized diopside. In the SEM image, the diopside structure is continuously in a trapezoidal shape. Fig. 4(b) presents the morphology relevant to the synthesized wollastonite. The SEM image showed the morphology of the wollastonite structure continuously in a plate shape. According to Fig. 4(c) and Table 3, the results of EDX analysis of the synthesized diopside showed that oxygen $(\mathrm{O})$, silicon $(\mathrm{Si})$, calcium and magnesium $(\mathrm{Mg})$ elements are the constituent elements of diopside. They also proved the nonavailability of the synthesized compound. Additionally, there $\operatorname{are~}_{\mathrm{Mg}^{2+}} \mathrm{Si}^{4+}$ and $\mathrm{Ca}^{2+}$ ions, meaning that as a result of the milling process, proper primary distribution of the raw materials occurred, causing uniform diopside to develop. According to Fig. 4(d) and Table 4, the results of the synthesized wollastonite showed that oxygen $(\mathrm{O})$, silicon $(\mathrm{Si})$ and calcium $(\mathrm{Ca})$ were the constituent elements of the wollastonite, and its non- availability was proved by the EDX analysis. It reveals that $\mathrm{Si}^{4+}$ and $\mathrm{Ca}^{2+}$ ions exist, meaning an appropriate primary distribution among the raw materials after the milling process which made uniform wollastonite.

Fig. 5(a, b) present the TEM images of the synthesized diopside and wollastonite in which the particles sizes of the diopsides and wollastonite were less than 100 $\mathrm{nm}$. It also showed the formation of interconnected agglomerates, and the range of nanostructure was observed. It is concluded that the synthesis of diopside and 
wollastonite nano-bioceramics by combining mechano-chemical and calcination processes is successful.

Fig. 6(a) presents the SEM image of wollastonite nano-bioceramic immersed in SBF up to 28 days, and suggests the development of an extensive apatite-like layer on the surface of wollastonite. The EDX analysis (Fig. 6(b) and Table 5) confirms the presence of $\mathrm{Ca}, \mathrm{P}$ and $\mathrm{O}$. Finally, it proves the development of a CaO- $\mathrm{P}_{2} \mathrm{O}_{5}$ film on the surface of the nano-bioceramic. Actually, the EDX analysis expresses high values related to $\mathrm{P}$ and $\mathrm{Ca}$, resulting in the creation of an apatite-like layer on the surface of wollastonite. Fig. 6(c) shows the SEM image of diopside nanobioceramic immersed in SBF up to 28 days, and Fig. 6(c) depicts the development of an apatite-like layer on the surface of diopside. This was confirmed via EDX analysis (Fig. 6(d) and Table 6), which presented high atomic percentage of $\mathrm{Ca}$ and $\mathrm{P}$, proving the development of a $\mathrm{CaO}-\mathrm{P}_{2} \mathrm{O}_{5}$ film on the surface of the diopside nano-bioceramic. It can be discussed that $\mathrm{Ca}^{2+}$ and $\mathrm{Mg}^{2+}$ made hydrolysis of the silica groups which generated the initial apatite crystals, and caused the $\mathrm{Ca}^{2+}$ and $\mathrm{Mg}^{2+}$ ions to be released. The ions migrated to the silica surface and finally a CaO$\mathrm{P}_{2} \mathrm{O}_{5}$ film was developed on the silica surface, and apatite crystals were nucleated $[26,27]$. With respect to the discussions, it is concluded that wollastonite and diopside are bioactive nano-bioceramics which can possess bone tissue biomineralization for biomedical applications. Fig. 7 depicts the mechanism of apatite formation.

Fig. 8 shows the cell viability related to wollastonite and diopside nanobioceramics. The cell viability test related to nano-bioceramics was conducted by utilizing MG-63 osteoblast cells and 1, 3 and 7 days of cell culture. It suggests a meaningful difference $(\mathrm{p}<0.05)$ for cell viability of nano-bioceramics. Cell viability and proliferation of MG-63 osteoblast cells incremented after 7 days, resulting in the compatibility cells of wollastonite and diopside, which caused the 
MG-63 osteoblast cells to be stimulated-an effective factor for the enhancement of cell growth, viability and proliferation. Moreover, nano-bioceramics lacked cytotoxicity by the MG-63 osteoblast cells.

Figs 9(a,b) present the optical microscope images of the culture medium including MG-63 osteoblast cells and diopside nano-bioceramic after alizarin red staining for 7 and 14 days. After 7 days, red veins (Fig. 9(a)) are observed. Fig. 9(b) presents optical microscope image after 14 days of alizarin red staining. The majority of areas in the image are red, showing that calcium activity in diopside increased after 14 days. In fact, diopside increased the secretion of calcium in the cells causing the $\mathrm{Ca}^{2+}$ ion to be released from the cell membrane. It persuaded the MG-63 osteoblast cells to secrete calcium, indicating the high bioactivity of diopside.

Similarly, Figs. 9(c, d) present the optical microscope images of the culture medium including MG-63 osteoblast cells and wollastonite nano-bioceramic after 7 and 14 days of alizarin red staining. After 14 days of alizarin red staining, calcium activity increased in wollastonite. In fact, wollastonite caused calcium secretion in the cells to increase, suggesting the release of the $\mathrm{Ca}^{2+}$ ion from the cell membrane.

Accordingly, wollastonite persuaded the MG-63 osteoblast cells to secrete calcium, showing that wollastonite is bioactive nano-bioceramic.

Fig. 9(e) presents the optical absorption (nm) according to the culture time (day) diagram after alizarin red staining related to diopside and wollastonite. According to the results, there was a meaningful difference $(\mathrm{p}<0.05)$ for wollastonite and diopside at 7 and 14 days.

Fig. 9(e) proves that increasing calcium activity related to two compounds after 14 days of alizarin red staining is much better and more outstanding than increasing calcium activity after 7 days of alizarin red staining related to two compounds. Moreover, by comparing the results of alizarin red staining between diopside and 
wollastonite, it is concluded that diopside has offered more acceptable and excellent performance compared to wollastonite. In fact, bioactivity of diopside was higher than that of wollastonite.

Fig. 10 presents the diagram related to the ALP rate according to culture time (day) of diopside and wollastonite after culturing for 3, 7 and 14 days. According to the results, there was a meaningful difference $(\mathrm{p}<0.05)$ for wollastonite and diopside at 3, 7 and 14 days. As can be observed, high alkaline phosphatase enzyme activity increased in the presence of diopside and wollastonite after 14 days of culture. Moreover, this enzyme has better activity in the presence of diopside compared to its activity in the presence of wollastonite. The obtained results showed that the secretion of alkaline phosphatase enzyme was in contact with diopside and wollastonite compounds from inside the osteoblast cells, causing the formation and restoration of the bone tissue to be accelerated.

Diopside had high cell responses compared to wollastonite. This can refer to the incorporation of $\mathrm{Mg}^{2+}$ into calcium-silicate network and, consequently, stability of the network and the enhancement of the cell responses.

\section{Conclusion}

Synthesis and characterization of diopside and wollastonite nano-bioceramics were successfully performed via mechano-chemical and calcination processes. The phase analyses showed that the diopside and wollastonite phases were developed in the $\mathrm{CaO}-\mathrm{SiO}_{2}-\mathrm{MgO}$ ternary and $\mathrm{CaO}-\mathrm{SiO}_{2}$ binary systems after milling for 20 $\mathrm{h}$ and calcination at $1200^{\circ} \mathrm{C}$. The TEM images proved particles size less than 100 $\mathrm{nm}$ for diopside and wollastonite. The results related to bio-mineralization and cell responses verified appropriate tissue biomineralization of wollastonite and diopside using the apatite-like layer on the surface of nano-bioceramics. Cell responses of wollastonite and diopside resulted in non-cytotoxicity by the MG-63 osteoblast cells, which confirmed their viability and cell proliferation. Alizarin red 
staining related to diopside and wollastonite proved high bioactivity and tissue biomineralization. The enhancement of the ALP enzyme related to diopside and wollastonite occurred in contact with the MG-63 osteoblast cells. With regard to the existence of $\mathrm{Mg}^{2+}$ in the calcium-silicate network and the stability network, diopside exhibited high biological and cell responses compared to wollastonite. Finally, wollastonie and diopside can be suggested as bioactive and biocompatible nano-bioceramics for biomedical applications.

\section{References}

[1] Borger, A., Supancic, P., Danzer, R., 2002. The ball on three balls test for strength testing of brittle discs: stress distribution in the disc. J. Eur. Ceram. Soc. $22,1425-1436$.

[2] Damani, R., Gstrein, R., Danzer, R. 1996. Critical notch - root radius effect in SENB - S fracture toughness testing. J. Eur. Ceram. Soc. 16, 695-702.

[3] De Aza, P.N., Luklinska, Z.B., Martinez, A., Anseau, M. R., Guitian. F., De Aza, S., 2000. Morphological and structural study of pseudowollastonite implants in bone. J. Microsc. 197, 60-67.

[4] Deutsches Institut fur Normung, 2003. DIN EN 623-3, Advanced Technical Ceramics - Monolithic Ceramics; General and Textural Properties - Part 3: Determination of grain size and size distribution (characterized by the linear intercept method), German version.

[5] Dorozhkin, S. V., 2010. Bioceramics of calcium orthophosphates. Biomaterials $31,1465-1485$.

[6] Fu, Q., Saiz, E., Rahaman, M. N., Tomsia, A. P., 2011. Bioactive glass scaffolds for bone tissue engineering: state of the art and future perspectives. Mater. Sci. Eng. C 31, 1245 - 1256. 
[7] Gou, Z., Chang, J., 2004. Synthesis and in vitro bioactivity of dicalcium silicate powders. J. Eur. Ceram. Soc. 24, $93-99$.

[8] Wu, C., Ramaswamy. Y., Zreiqat, H., "Porous diopside $\left(\mathrm{CaMgSi}_{2} \mathrm{O}_{6}\right)$ scaffold: A promising bioactive material for bone tissue engineering", Journal of Acta Biomaterialia, 2010, vol 6, PP 2237 - 3345.

[9] Kokubo, T., Takadama, H., "How useful id SBF in predicting in vivo bone bioactivity”, biomaterials, 2006, vol 27, PP $2907-2915$.

[10] Aza, N., Zofia, B. and Anseau, M., "Bioactivity of diopside ceramic in human”, Journal of Biomed Mater Res Part B: Appl Biomater, 2005, vol 73, PP 54 -60 .

[11] Nonami, T., and Tsutsumi, S., "Study of diopside ceramics for biomaterials", Joumal of Materials Science: Materials in Medicine, 1999, vol 10, PP 475 - 479.

[12] Nakajima, S., "Experimental studies of heading process on reinforcement ceramic implantation in rabbit mandible", Journal of Biomedical Materials Research Part B: Applied Biomaterials, 1990, vol 90, PP 525 - 553.

[13] Nakajima, S., Harada, Y, Kurishara, Y, Wakatsuki, T., and Noma, H., "Physicochemical characteristics of new reinforcement ceramic implant" Shikwa Gakuho 1989, Vol 89, PP 1709 - 1717.

[14] Nonami, T., "Developmental - study of diopside for use as implant material" Journal of Mat Res Soc Symp Proc, 1992, vol 252, PP 87-92

[15] Wu, C., Chang, J., "Degaradation bioactivity, and cytocompatibility of diopside, akermanite, and bredigite ceramics" journal of biomedical Materials Reasearch Part B: Applied Biomaterials, 2007, Vol 83, PP 60 - 153.

[16] Wu, C., Chang, J., Wang, J., Ni, S., and Zhai, W., "Preparation and characteristics of a calcium magnesium silicate (bredigite) bioactive ceramic", Joumal of Biomaterials, 2005, Vol 26, PP 2925 - 2931. 
[17] Shackelford, J. F, Doremus, R. H, Handbook ceramic and materials structure, properties and processing, Springer, 2008.

[18] Long, L. H, Chen, L. D, Chang, J, "Low temperature fabrication and characterizaition of $\beta-\mathrm{CaSiO}_{3}$ ceramics", Ceramics intemational, 2006, Vl 32, PP $457-460$.

[19] Schlumpm W., Grewe, H., New Materials by Mechanical Alloying Techniques, eds. E. Arztand and L. Schultz, DGM, Oberursel, 1989.

[20] Eckert, J., Holzer, J.c., Krill, C. E., Johnson, W. L., "Mechanically driven alloying and grain size changes in nanocrystalline $\mathrm{Fe}-\mathrm{Cu}$ powders". J. Mater. Res, Vol. 7, PP. 1751 - 1761, 1992.

[21] Ghomi, H., Emadi, R., Haghjooyeh Javamard, S., "Preparation of nanostructure bioactive diopside scaffolds for bone tissue engineering by two near net shape manufacturing techniques", J. Mat. Lett, Vol. 167, PP. 157-160, 2016.

[22] Monshi, A., Foroughi, M. and Monshi, M., 2012, "Modifid Scherrer Equation to Estimate More Accurately Nano - Crystallite Size Using XRD”, J. Nano Science and Engineering, Vol. 2, No. 3, PP. $154-160$.

[23] T. Kokubo, H.Takadama, "How useful is SBF in predicting in vivo bone bioactivity?", J. Biomaterials, Vol.27, 2907-2915, 2006.

[24] Lu, L., Lai, M. O., Mechanical Alloying, Kluwer Academic Publisher, Boston, 1998.

[25] Williamson, G. K., Hall, W. H., "X - ray line broadening from filed aluminum and wolfram", Acta Metall., Vol. 1, PP. 22 - 31, 1953.

[26] C. Wu, J. Chang, "A review bioactive silicate ceramics", Journal of Biomedical Materials, Vol.8, pp.1-12, 2013.

[27] K. Khoshroo, T.S. Jafarzadeh, F. Moztarzadeh, M. Tahriri, H. Jazayeri, L. Tayebi, "Development of 3D PCL microsphere/ $/ \mathrm{TiO}_{2}$ nanotube composite scaffolds 
for bone tissue engineering", Journal of Materials Science and Engineering C, Vol.70, pp.586-598, 2017.
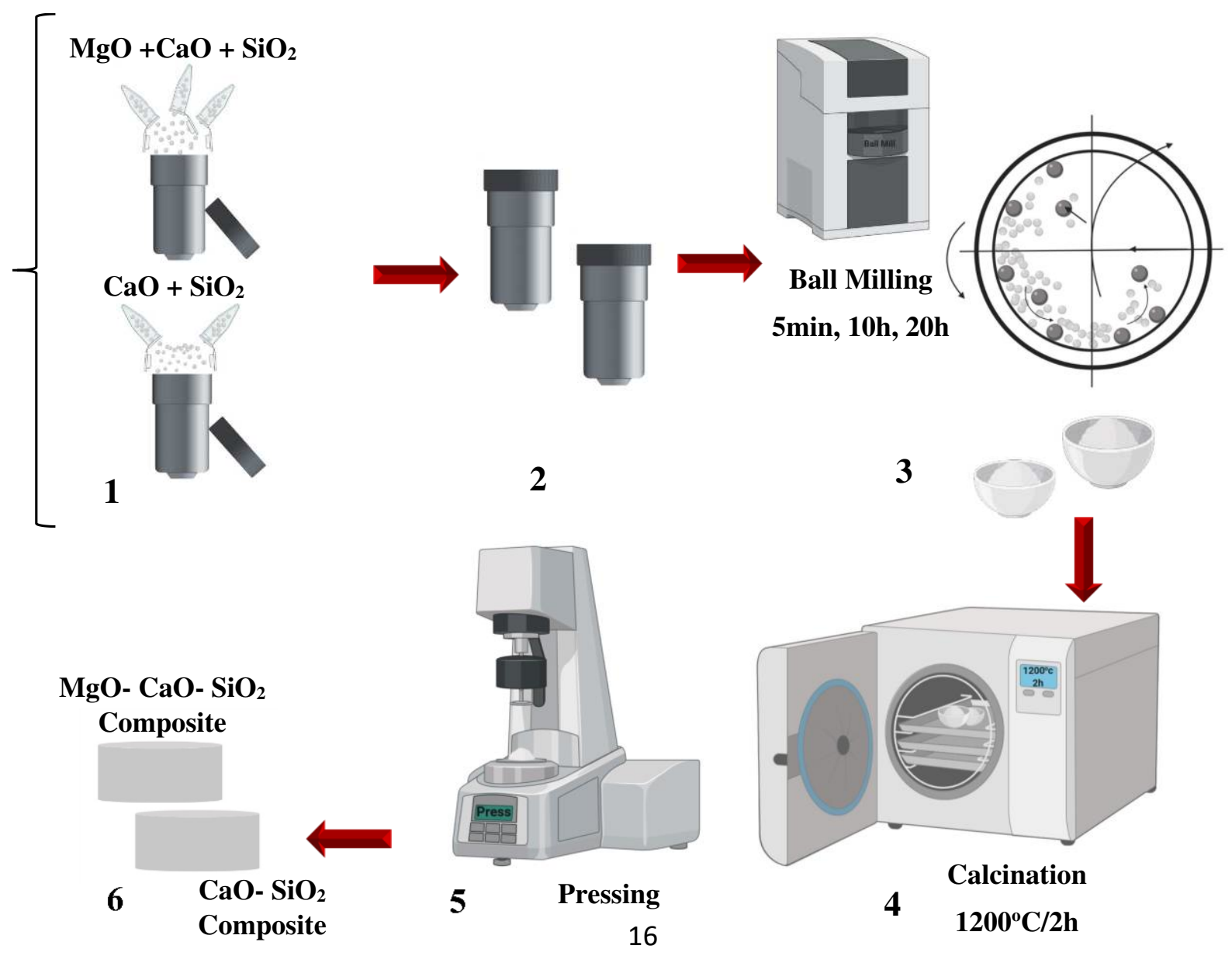
Fig. 1.The mechanism of synthesis of the diopside and wollastonite nanobioceramics

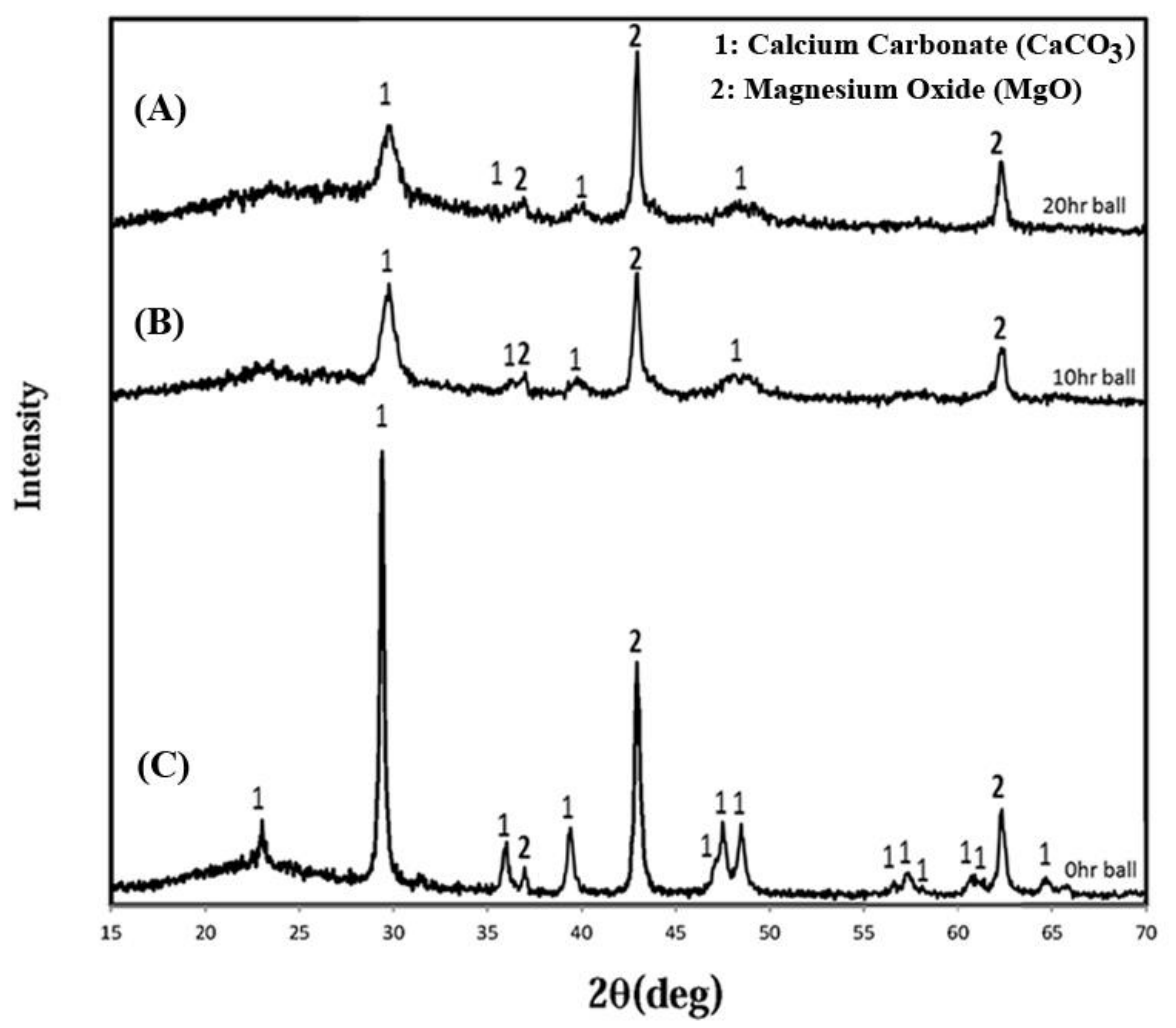

Fig. 2. XRD patterns of the milled powders among raw materials related to the diopside phase: (a) $5 \mathrm{~min}$, (b) $10 \mathrm{~h}$, and (c) $20 \mathrm{~h}$ 


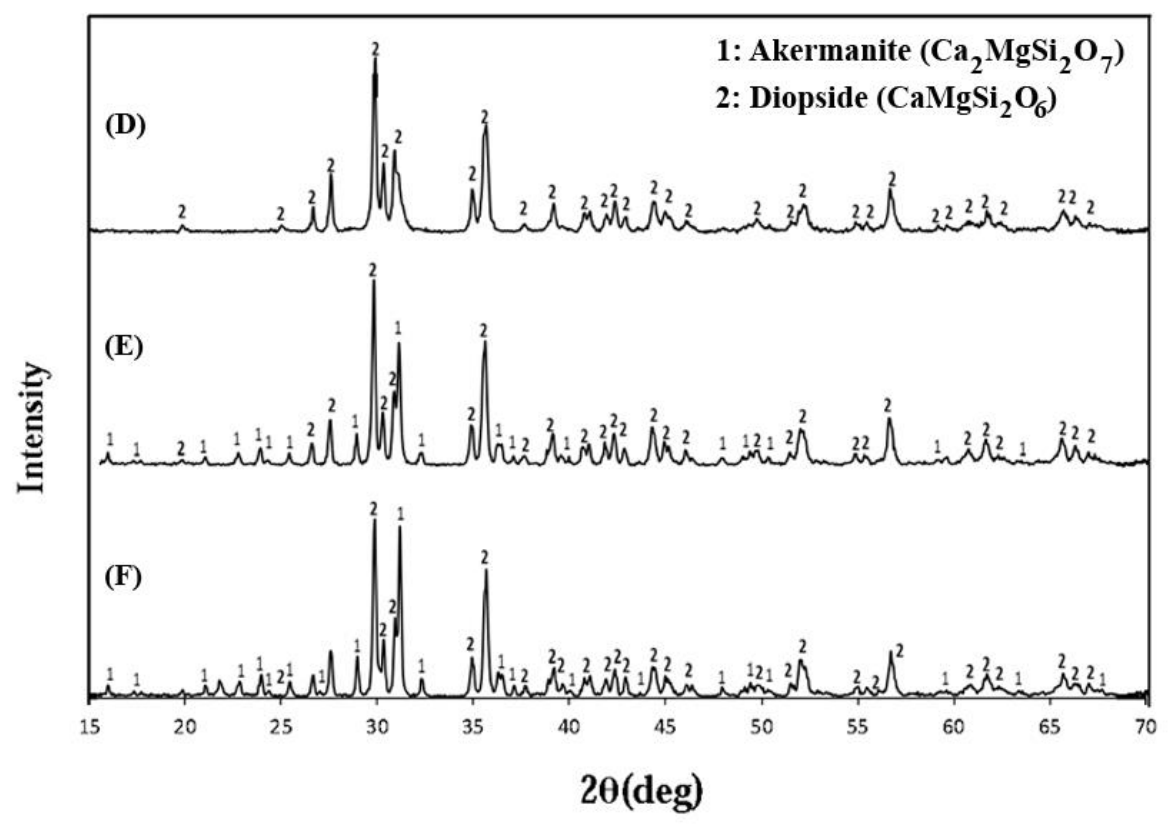

Fig. 2. XRD patterns of the sintering process of the milled powders at $1200{ }^{\circ} \mathrm{C}$ for formation of diopside phase: (d) $5 \mathrm{~min}$, (e) $10 \mathrm{~h}$, and (f) $20 \mathrm{~h}$

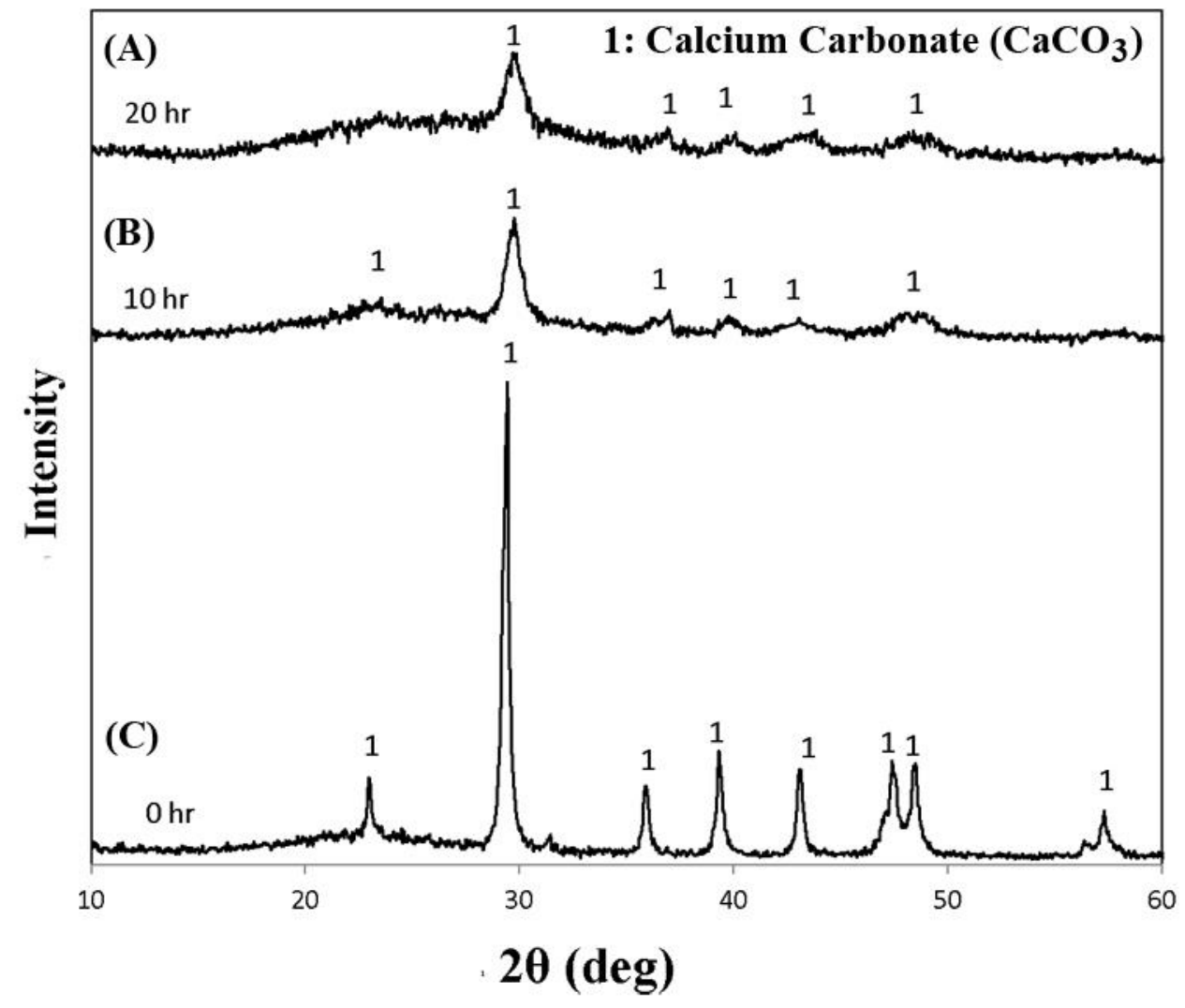

Fig. 3. XRD patterns of the milled powders among raw materials related to the wollastonite phase: (a) $5 \mathrm{~min}$, (b) $10 \mathrm{~h}$, and (c) h 


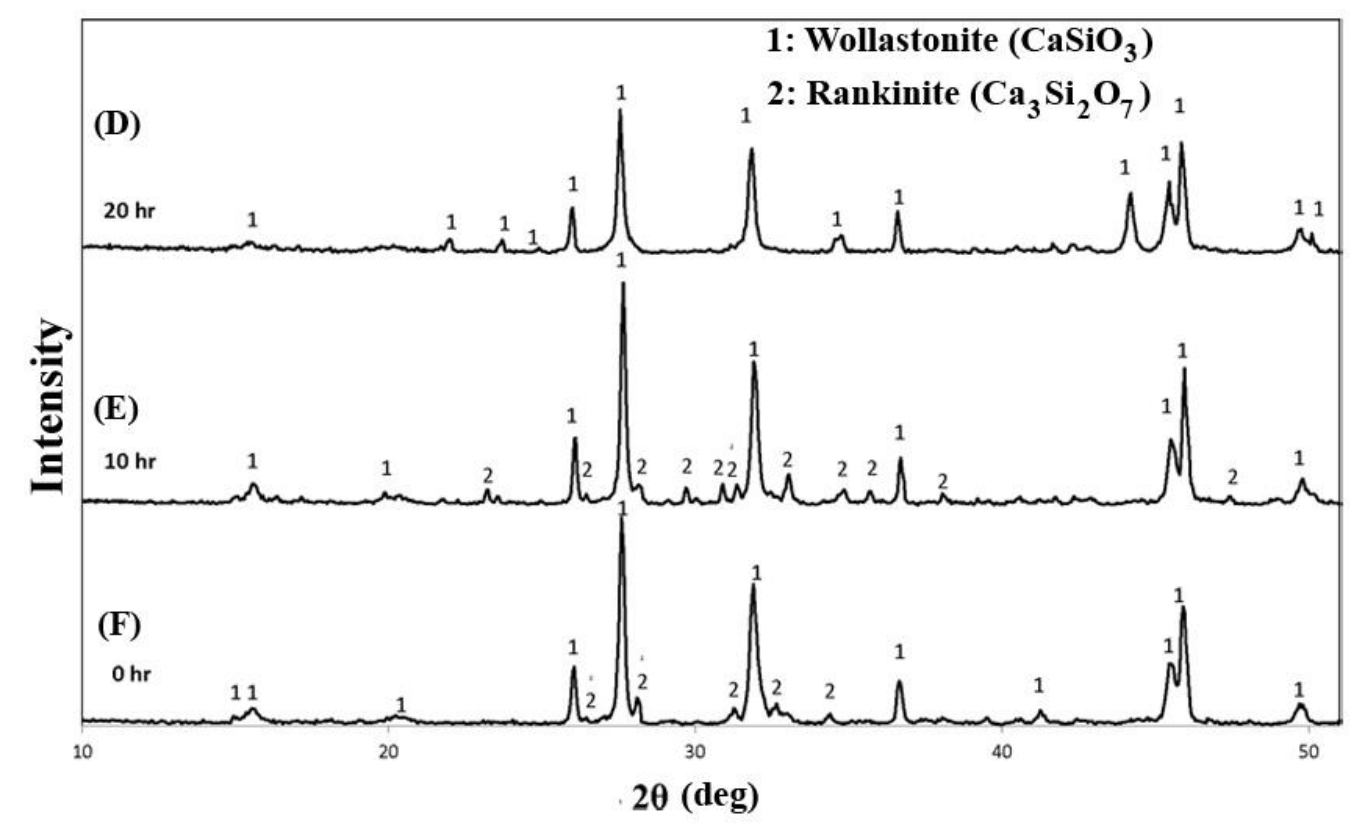

Fig. 3. XRD patterns of the sintering process of the milled powders at $1200{ }^{\circ} \mathrm{C}$ for wollastonite phase formation : (d) $5 \mathrm{~min}$, (e) $10 \mathrm{~h}$, and (f) $20 \mathrm{~h}$

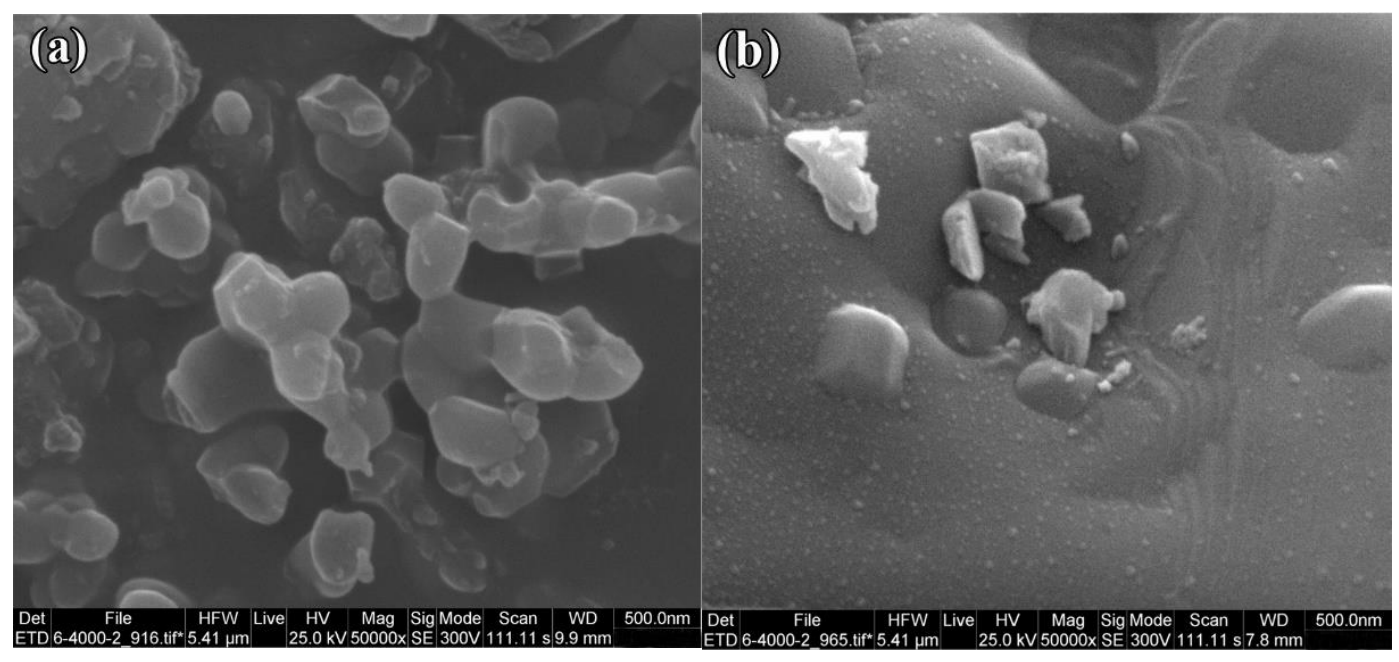


(c)

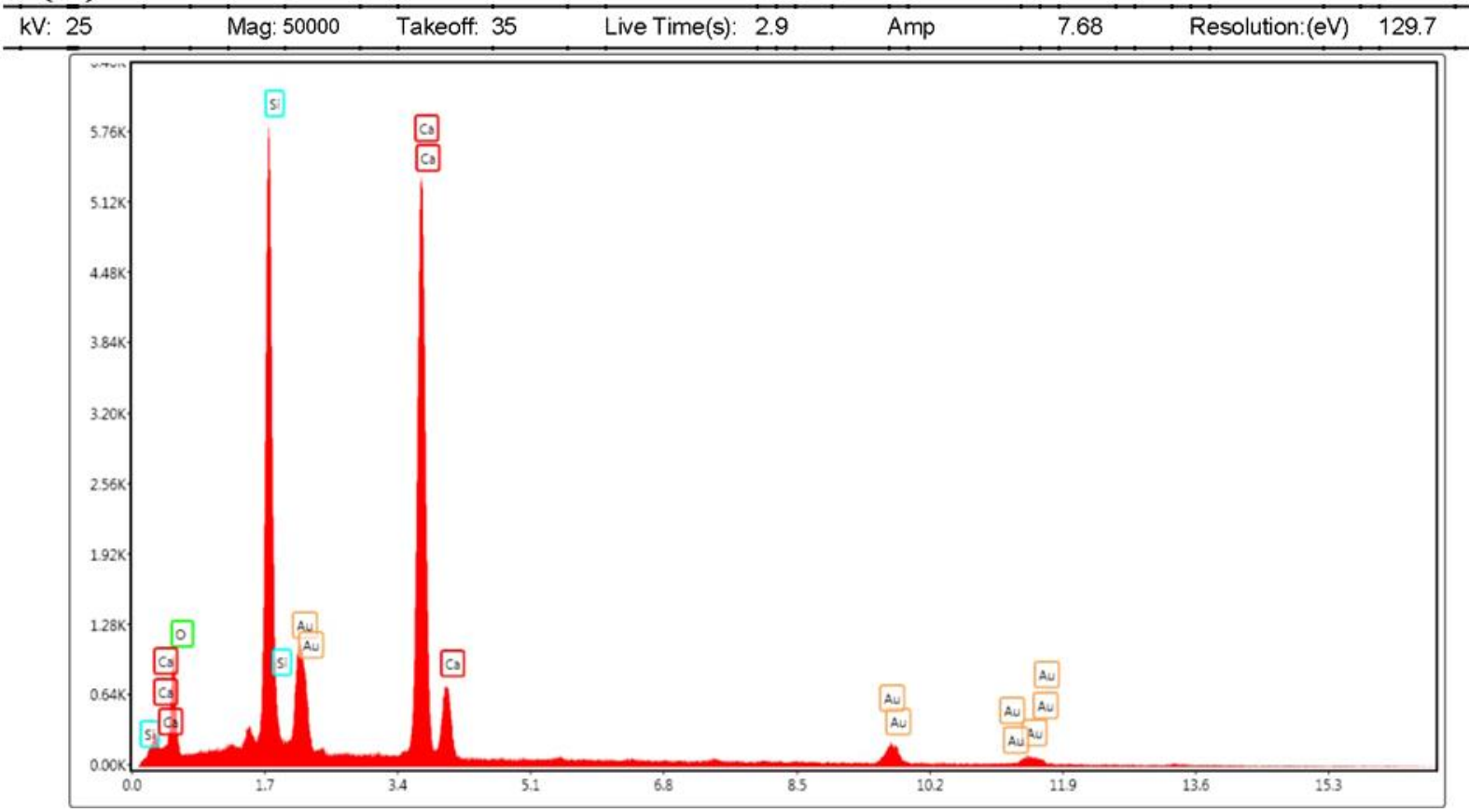

(d)

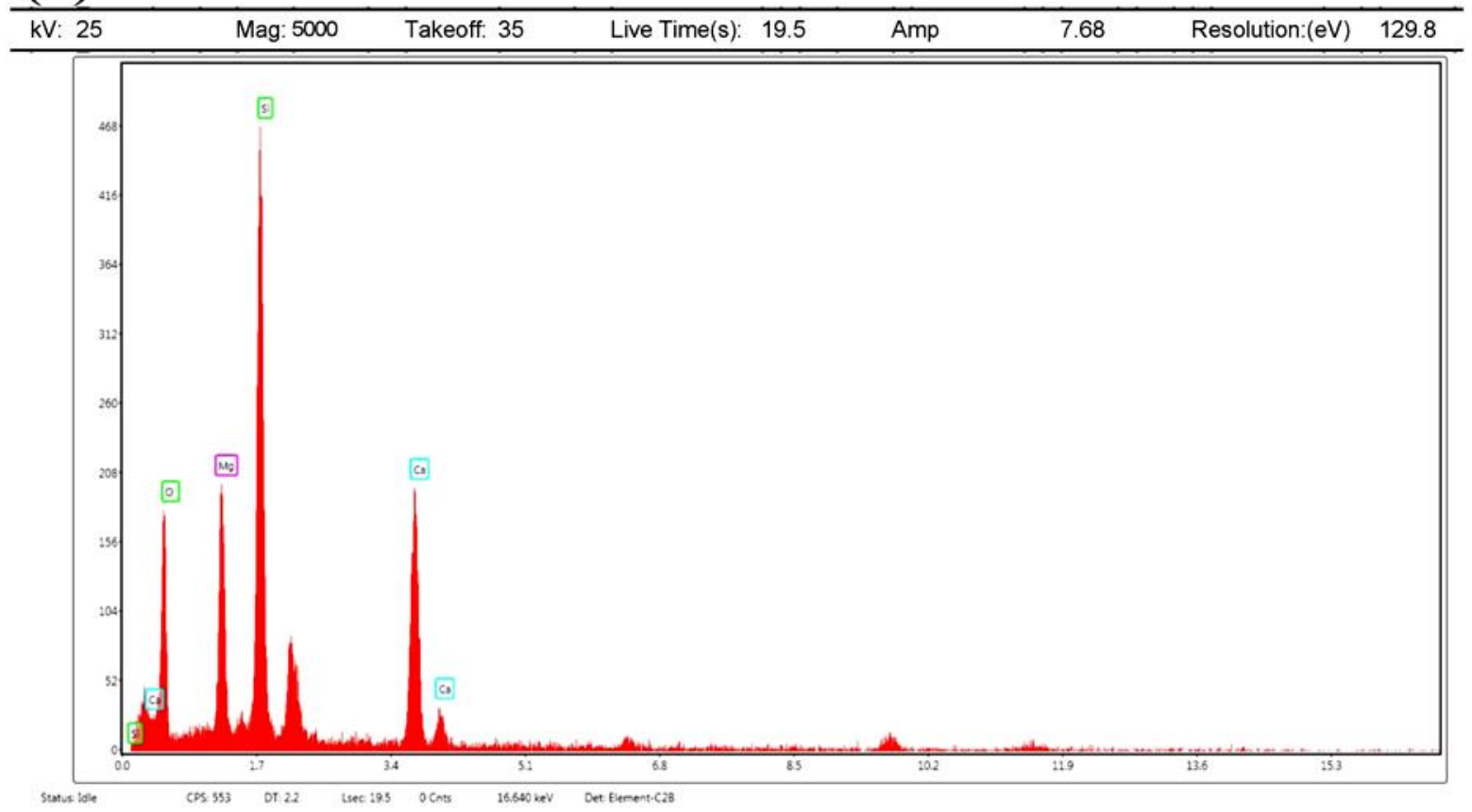

Fig. 4. SEM images of (a) synthesized diopside and (b) synthesized wollastonite; (c) EDS analysis of synthesized diopside; (d) EDX analysis of the synthesized wollastonite 
(a)

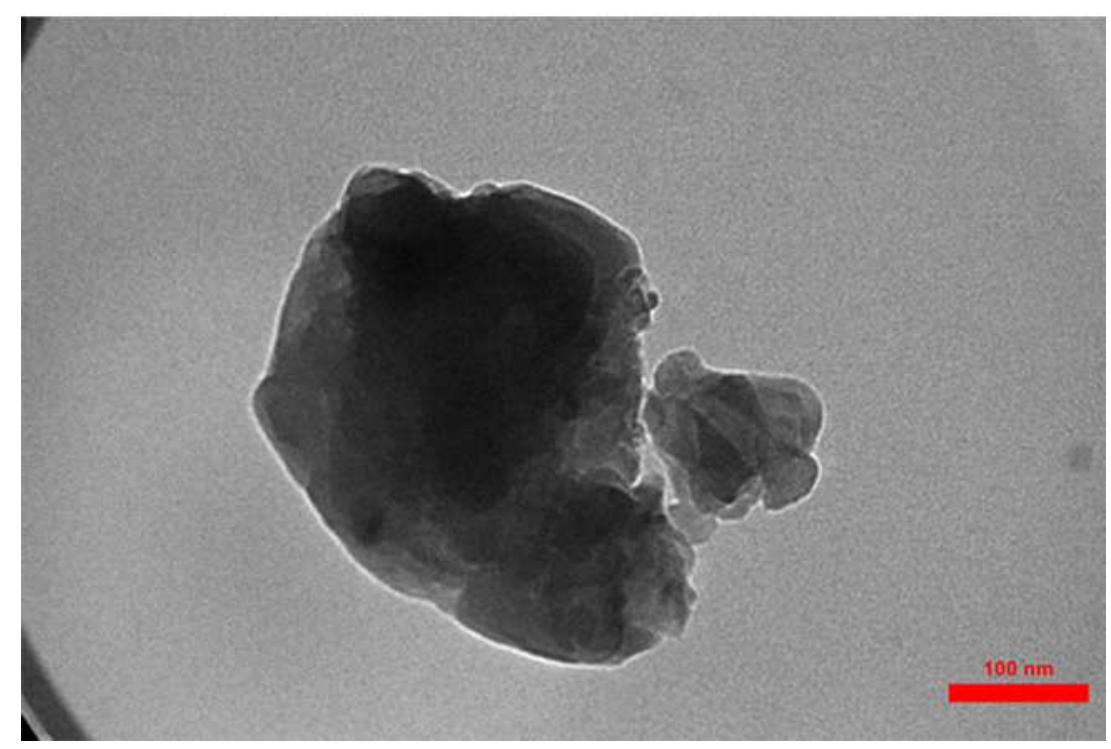

(b) 


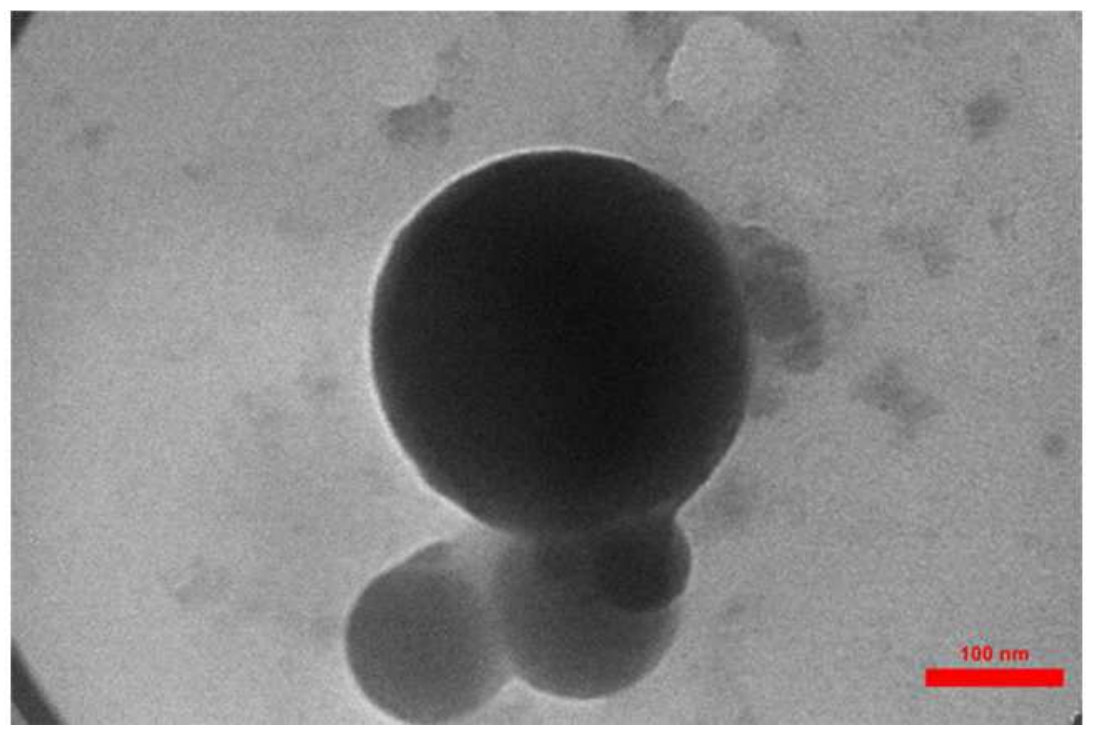

Fig. 5. TEM images of (a) synthesized diopside and (b) synthesized wollastonite

(a)

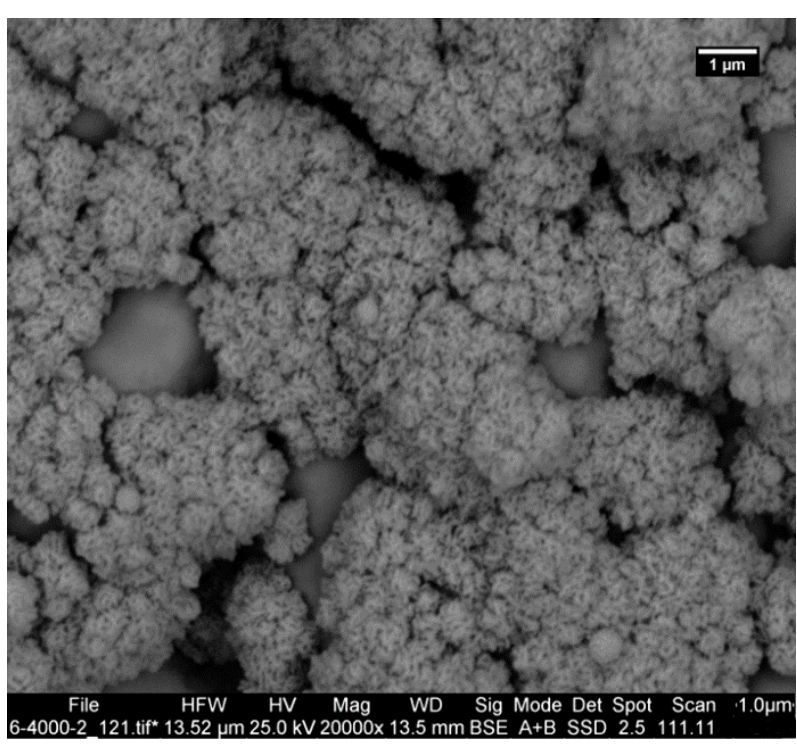

(b) 


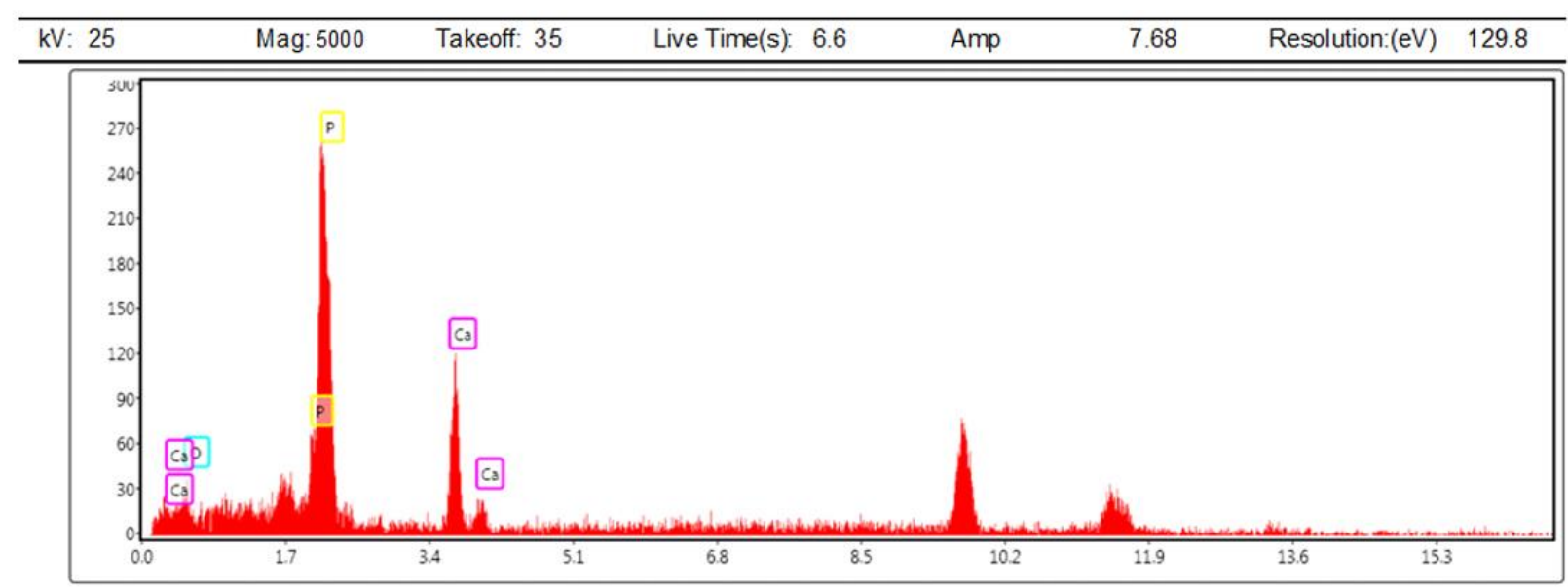

(c)

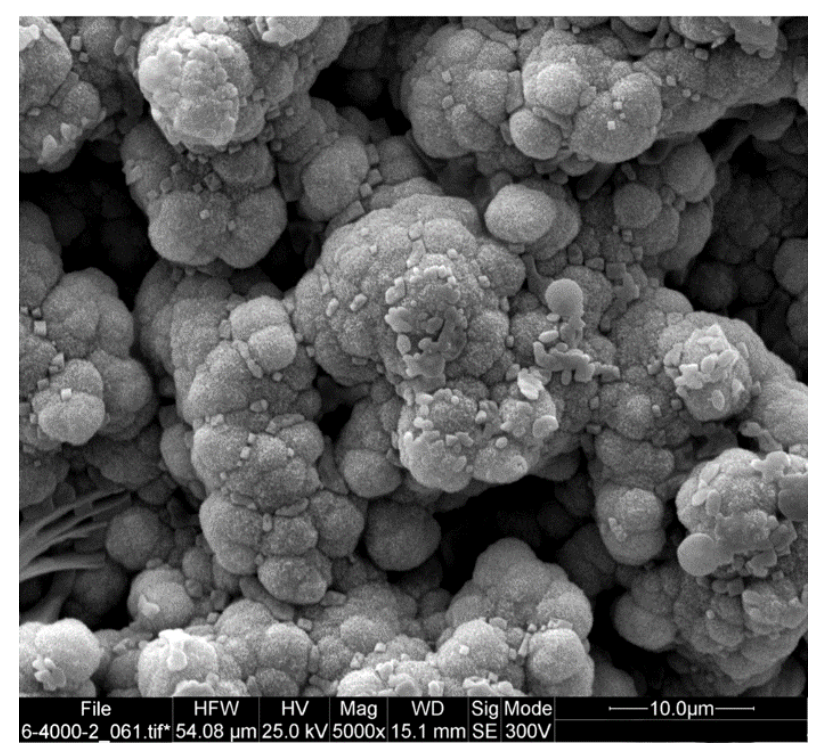


(d)

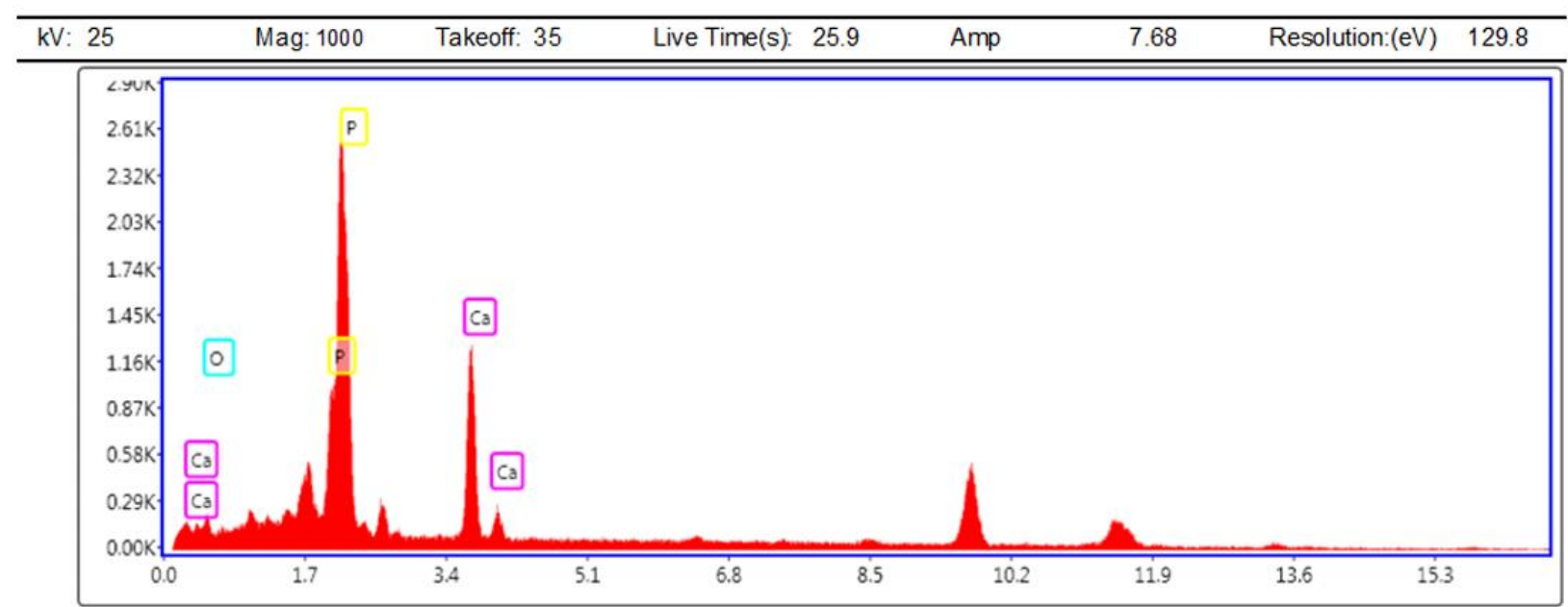

Fig. 6. (a) SEM image of wollastonite in immersed SBF up to 28 days, (b) EDX analysis, (c) SEM image of diopside immersed in SBF up to 28 days, (d) EDX analysis

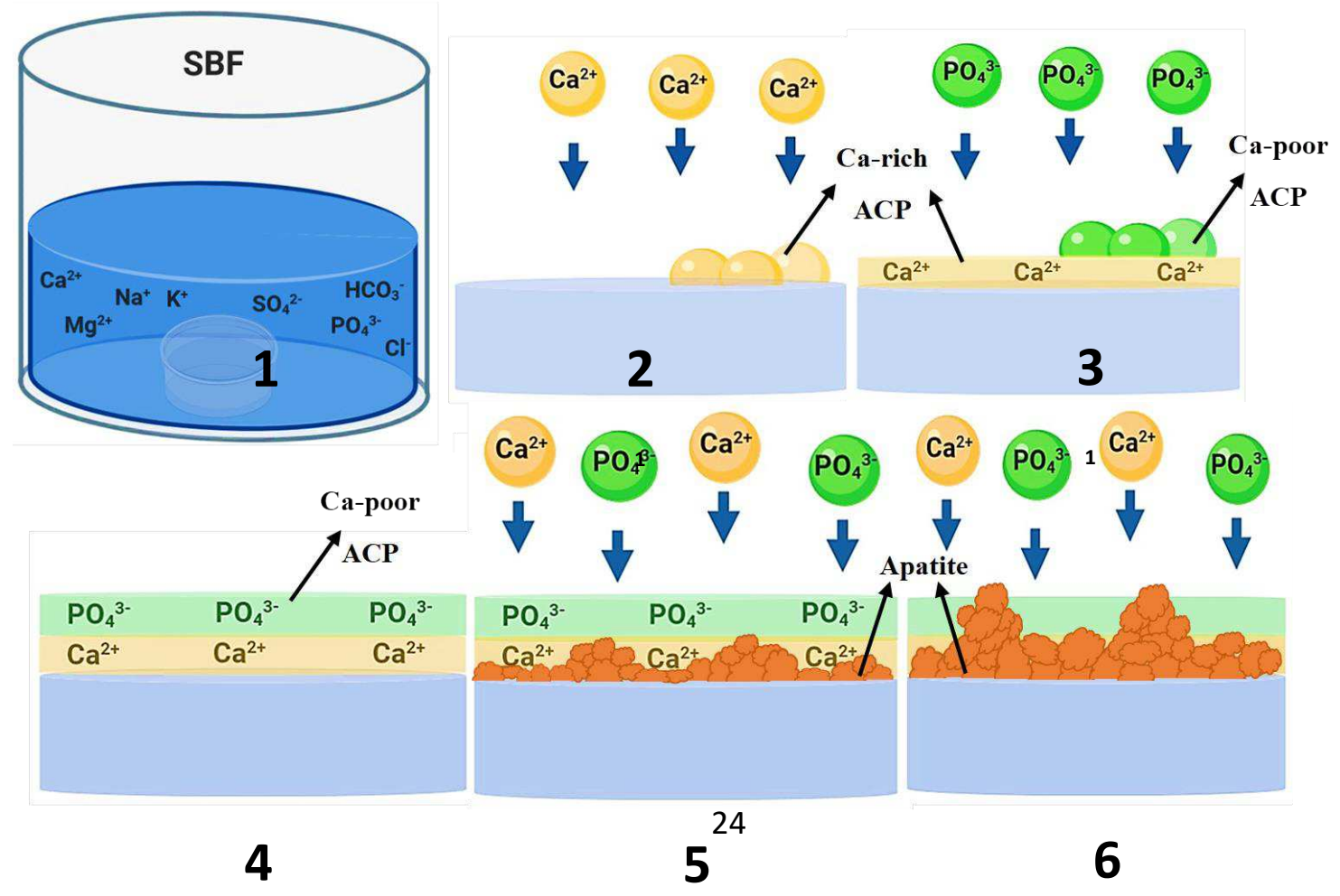


Fig. 7. The mechanism of apatite formation on bioactive diopside and wollastonite nano-bioceramics

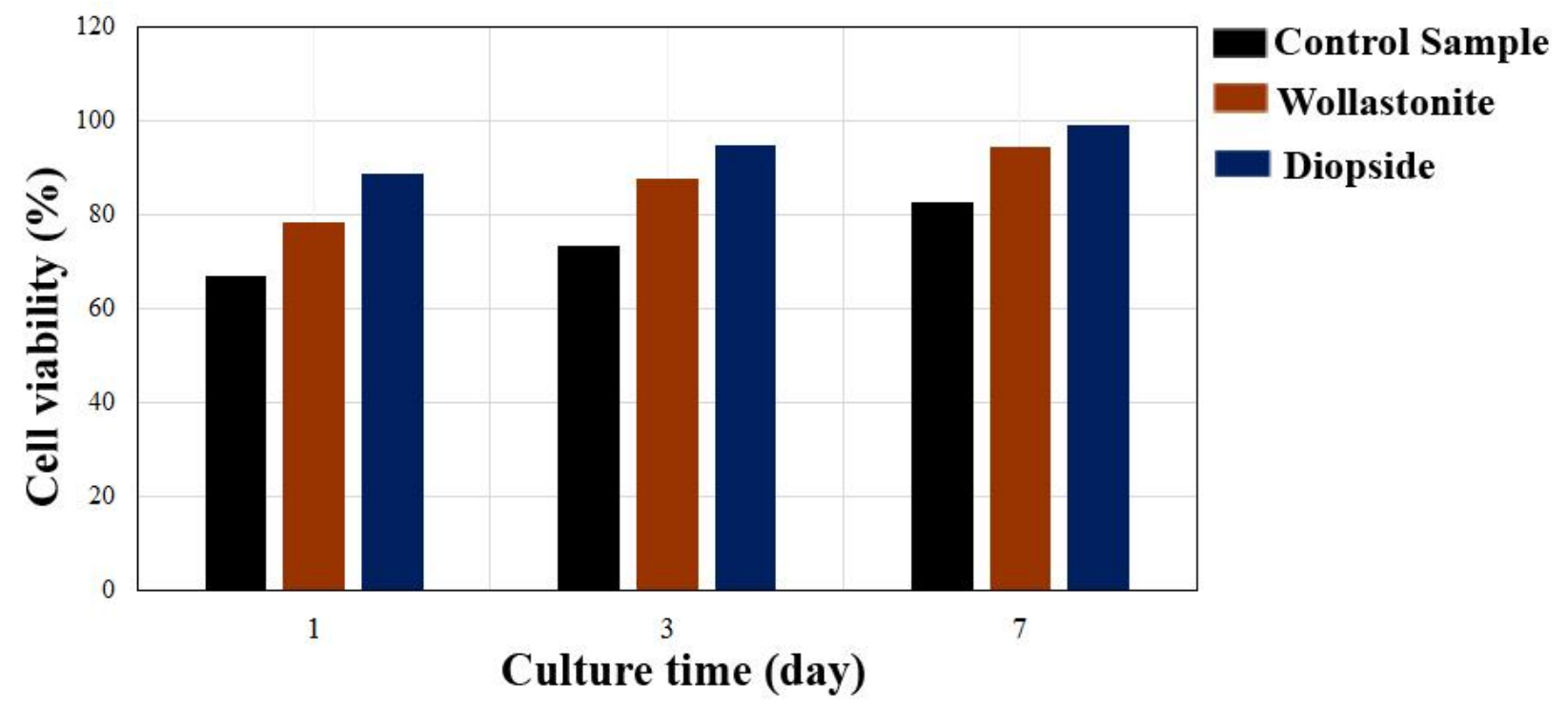

Fig. 8. Results of cell viability related to wollastonite and diopside nanobioceramics 
(a)

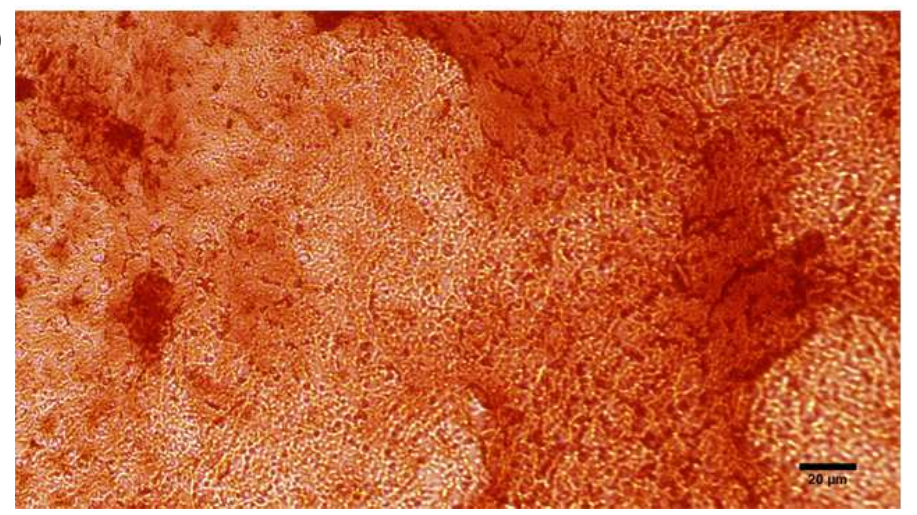

(b)

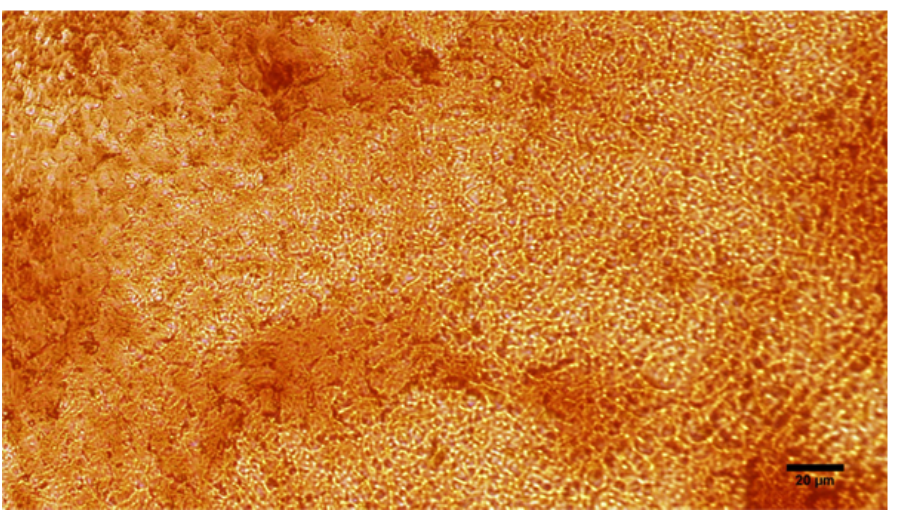

(c)

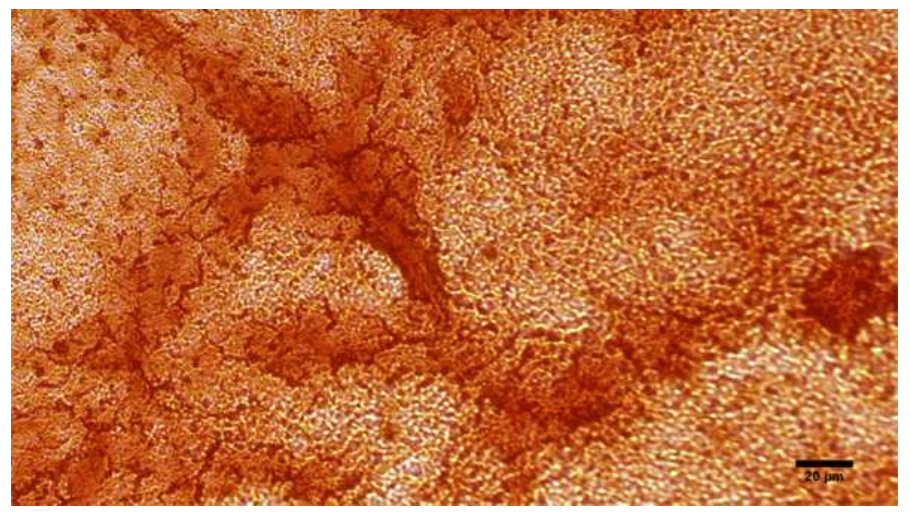

(d) 

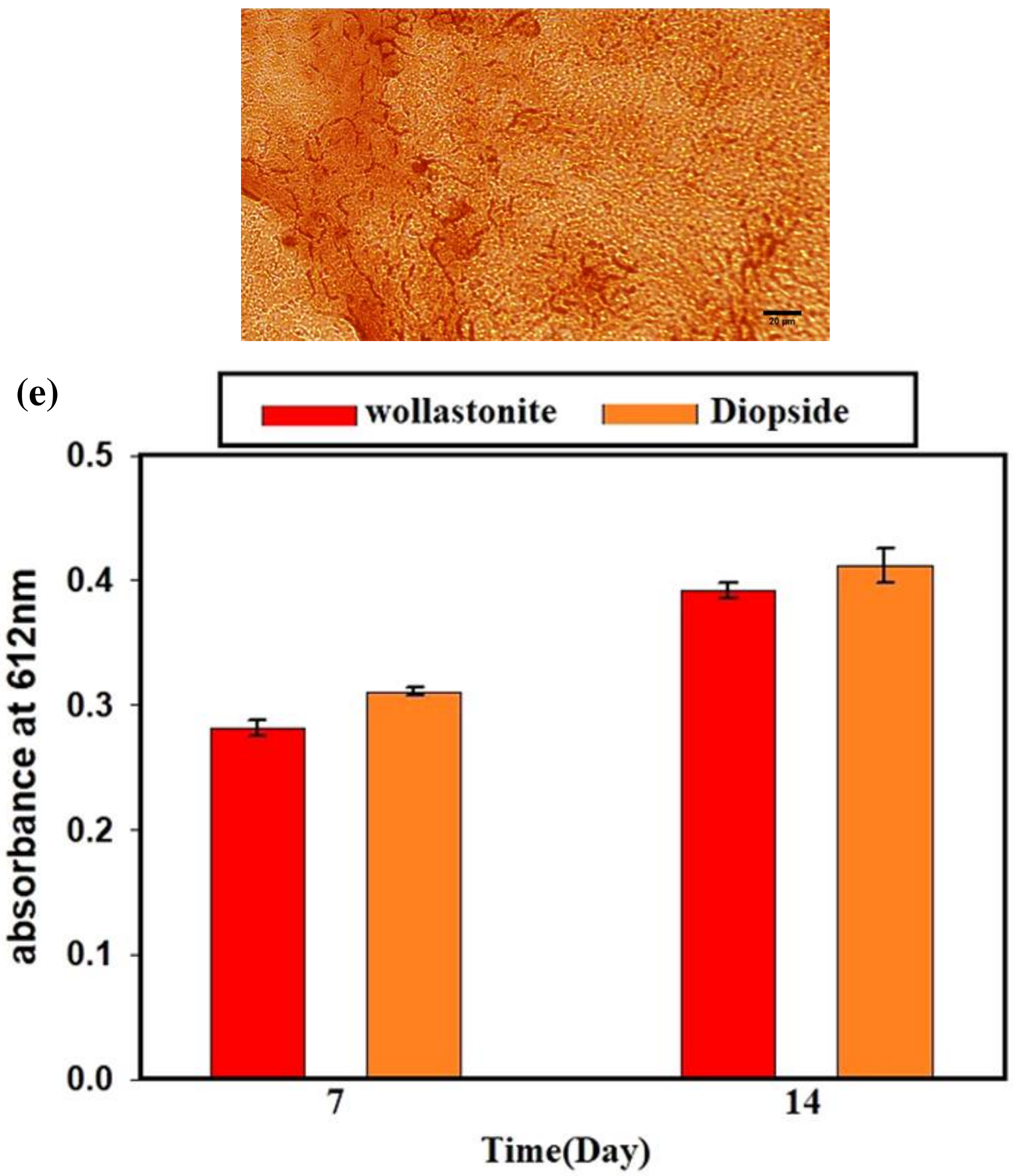

Fig. 9. (a) and (b) Optical microscope images of the culture medium (MG - 63 osteoblast cells and diopside) obtained by alizarin red staining, (c) and (d) Optical microscope images of the culture medium (MG - 63 osteoblast cells and wollastonite) obtained by alizarin red staining, and diagram of optical absorption according to the culture time (day) after alizarin red staining relevant to diopside 
and wollastonite compounds, and (e) Optical density-culture time (day) diagram of alizarin red staining

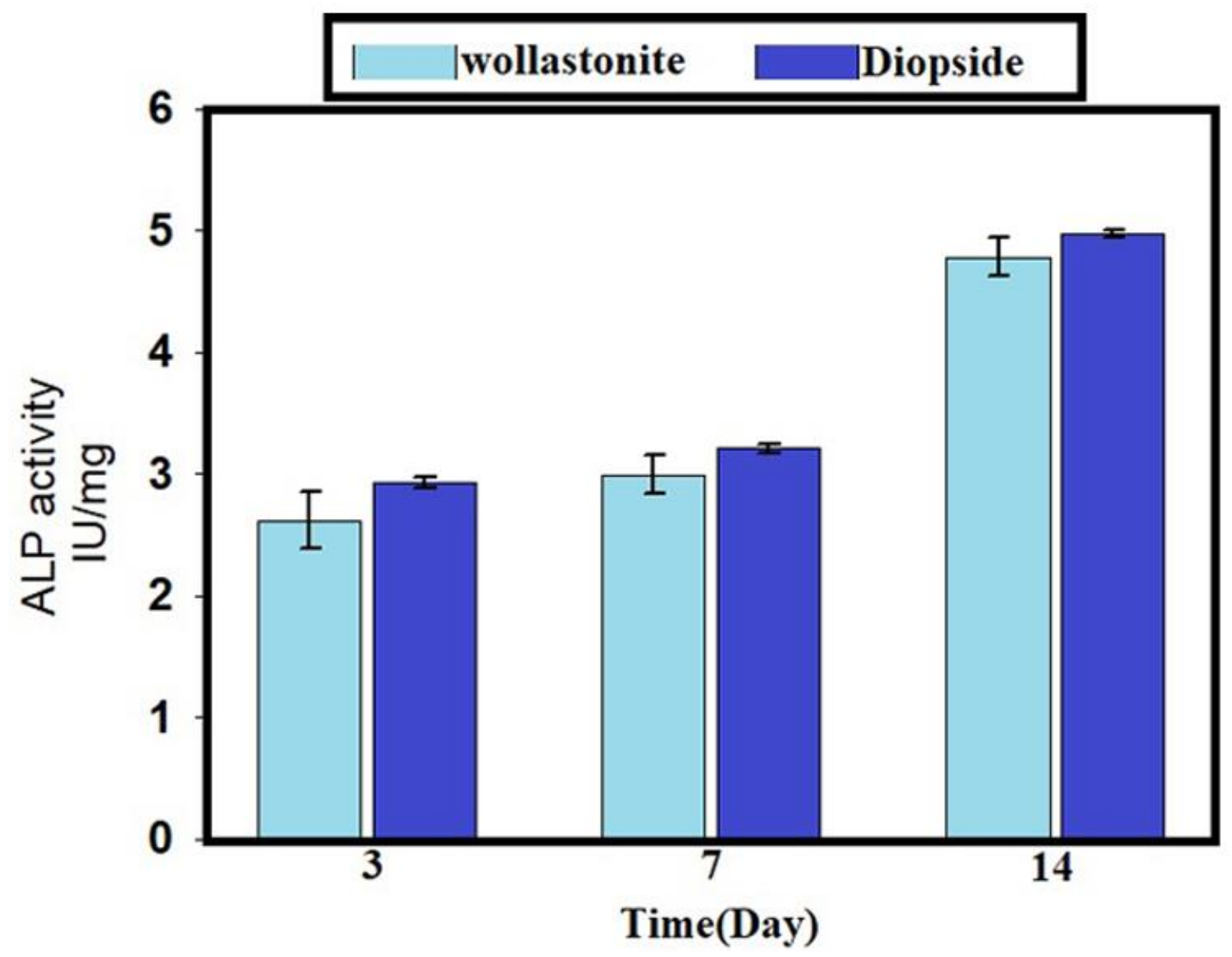

Fig.10. Diagram of ALP rate - culture time (day) after culturing for 3, 7 and 14 days related to diopside and wollastonite compounds 
Table 1. Calculated values of crystallite size of diopside and wollastonite by the Scherrer method

\begin{tabular}{ccccc}
\hline $2 \theta$ & $\operatorname{Cos}(\theta)$ & FWHM & $\beta$ & D \\
\hline 27.58 & 0.971 & 0.1476 & 0.0025 & 55 \\
29.86 & 0.966 & 0.1968 & 0.0034 & 41 \\
30.31 & 0.965 & 0.1476 & 0.0025 & 56 \\
41.89 & 0.933 & 0.1968 & 0.0034 & 43 \\
44.37 & 0.925 & 0.2460 & 0.0042 & 35 \\
\hline
\end{tabular}


Table 2. Calculated values of the crystallite size of wollastonite by the Scherrer method

\begin{tabular}{ccccc}
\hline $2 \theta$ & $\operatorname{Cos}(\theta)$ & FWHM & $\beta$ & $\mathrm{D}$ \\
\hline 25.987 & 0.97 & 0.1476 & 0.0025 & 61 \\
27.55 & 0.971 & 0.1968 & 0.0034 & 47 \\
31.83 & 0.961 & 0.1968 & 0.0034 & 47 \\
45.88 & 0.92 & 0.1968 & 0.0034 & 49 \\
\hline
\end{tabular}


Table 3. Results of the EDX analysis of the synthesized diopside and wollastonite

\begin{tabular}{cccc}
\hline Element & Weight\% & Atomic \% & Net Int. \\
\hline O K & 41.79 & 56.95 & 68.47 \\
MgK & 14.46 & 12.97 & 86.53 \\
SiK & 27.02 & 20.98 & 211.76 \\
CaK & 16.73 & 9.1 & 109.25 \\
\hline
\end{tabular}


Table 4. Results of the EDX analysis of the synthesized wollastonite

\begin{tabular}{cccc}
\hline Element & Weight\% & Atomic \% & Net Int. \\
\hline O K & 26.44 & 48.56 & 2583.16 \\
SiK & 21.06 & 22.03 & 18004.71 \\
CaK & 36.95 & 27.09 & 22010.61 \\
$\mathrm{AuL}$ & 15.54 & 2.32 & 1217.38 \\
\hline
\end{tabular}




\begin{tabular}{|c|c|c|c|c|c|c|}
\hline & & Element & $\begin{array}{c}\text { Weight } \\
\%\end{array}$ & $\begin{array}{c}\text { Atomic } \\
\%\end{array}$ & Net Int. & \\
\hline & & $\mathrm{OK}$ & 46.31 & 65.68 & 45.68 & \\
\hline & & P K & 23.58 & 17.05 & 168.82 & \\
\hline & & P K & 23.58 & 17.05 & 168.82 & \\
\hline Table & 5 & $\mathrm{CaK}$ & 30.11 & 18.28 & 177.6 & Results of \\
\hline
\end{tabular}


Table 6. Results of the EDX analysis of the synthesized diopside biomineralization 


\begin{tabular}{cccc}
\hline Element & $\begin{array}{c}\text { Weight } \\
\text { \% }\end{array}$ & $\begin{array}{c}\text { Atomic } \\
\text { \% }\end{array}$ & Net Int. \\
\hline O K & 36.59 & 56.08 & 80.53 \\
P K & 28.41 & 21.42 & 497.56 \\
CaK & 35.1 & 23.76 & 559.6 \\
\hline
\end{tabular}


Figures

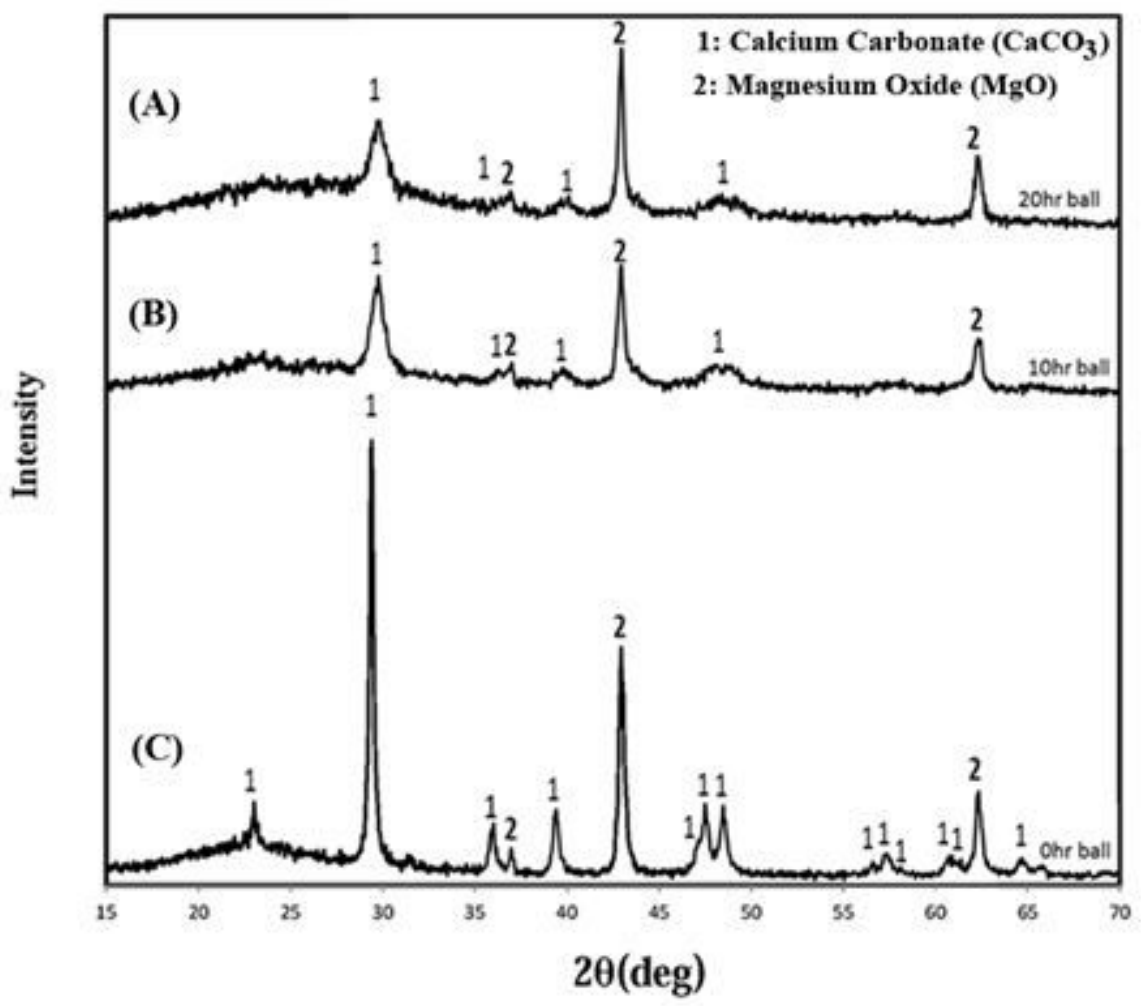

Figure 1

The mechanism of synthesis of the diopside and wollastonite nano-bioceramics

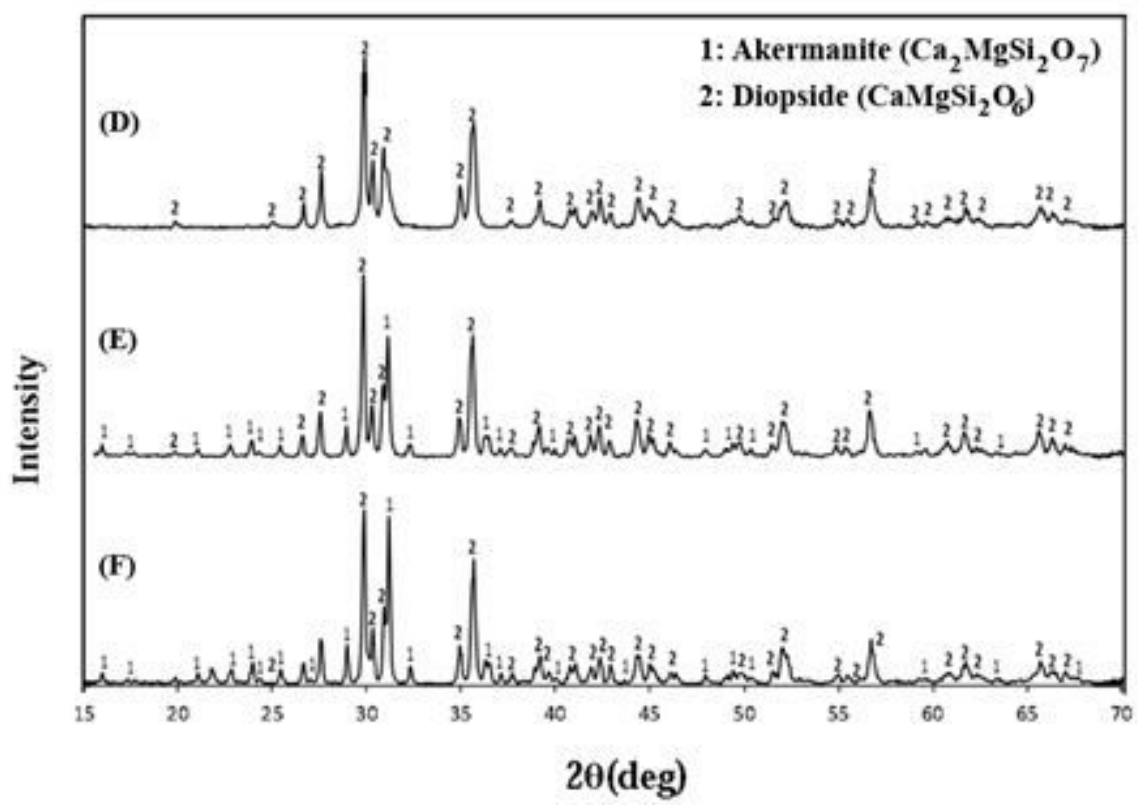

Figure 2 
XRD patterns of the sintering process of the milled powders at $1200 \otimes$ for formation of diopside phase: (d) $5 \mathrm{~min},(\mathrm{e}) 10 \mathrm{~h}$, and (f) $20 \mathrm{~h}$

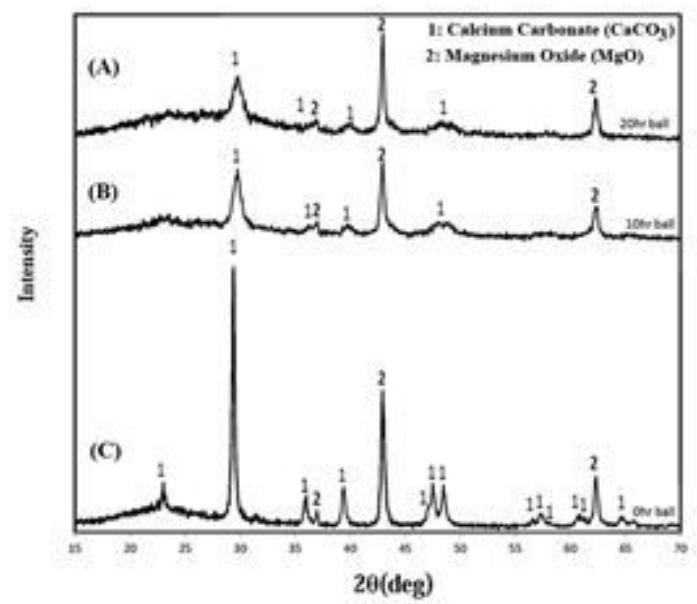

Figure 3

XRD patterns of the milled powders among raw materials related to the diopside phase: (a) 5 min, (b) 10 $\mathrm{h}$, and (c) $20 \mathrm{~h}$

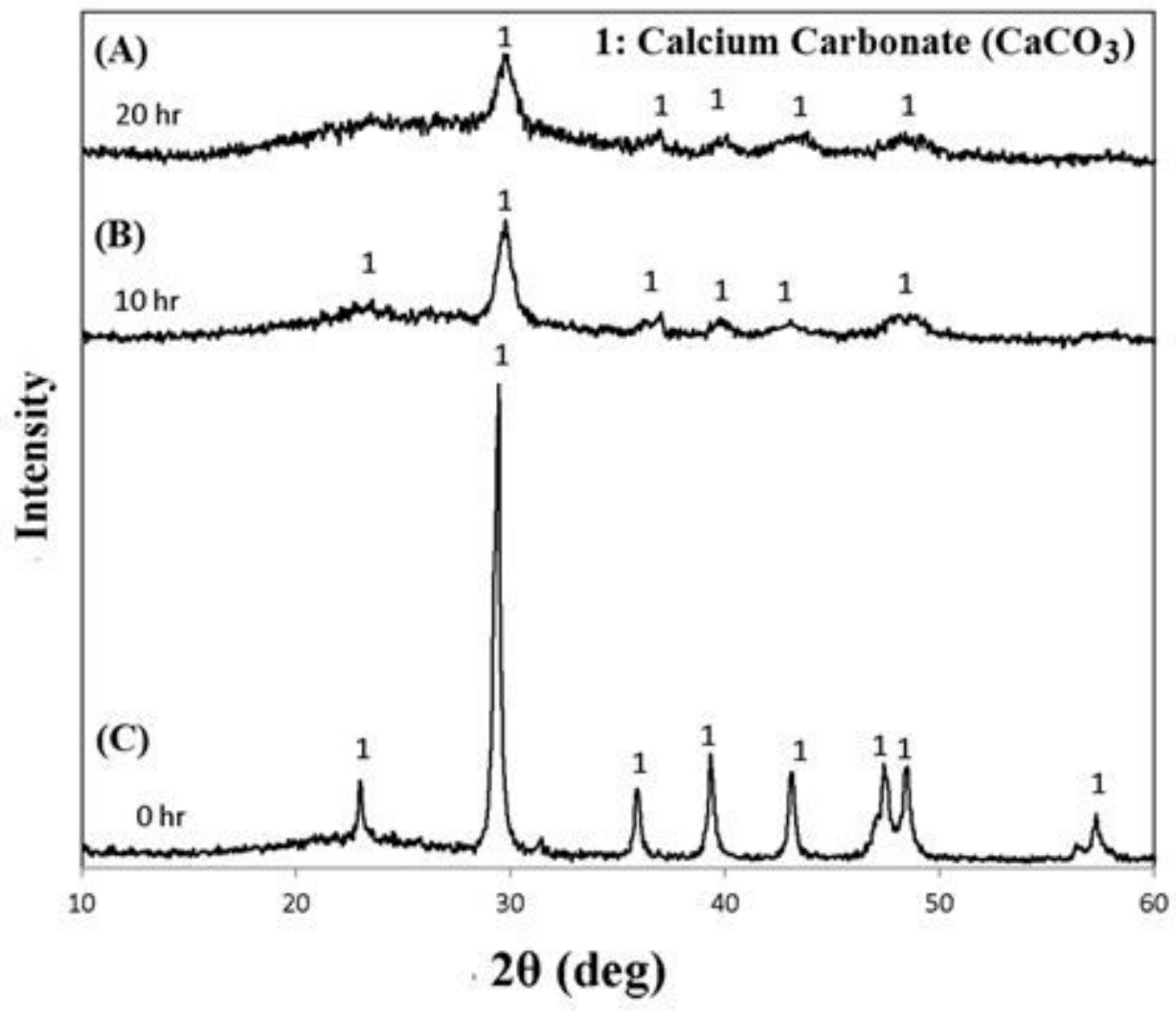

Figure 4

XRD patterns of the milled powders among raw materials related to the wollastonite phase: (a) 5 min, (b) $10 \mathrm{~h}$, and (c) h 


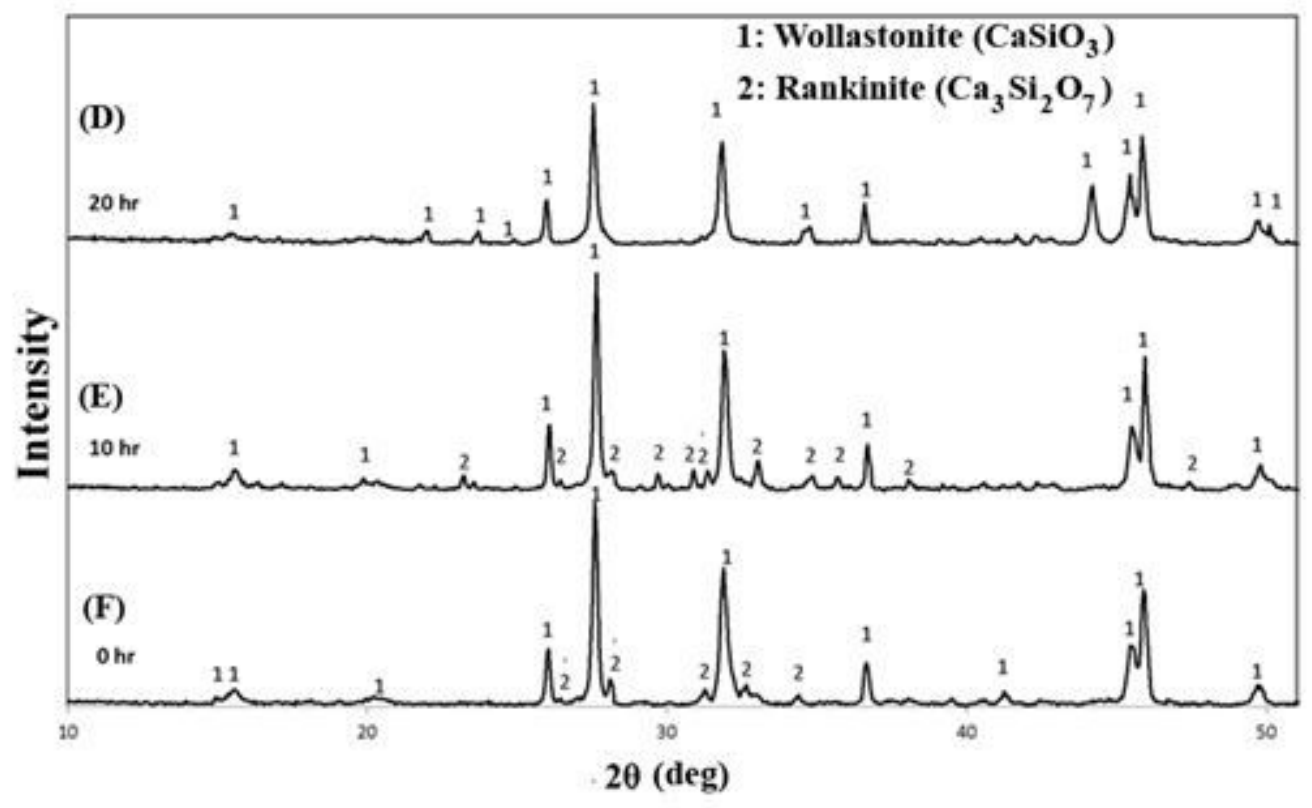

Figure 5

XRD patterns of the sintering process of the milled powders at $1200 \otimes$ for wollastonite phase formation : (d) $5 \mathrm{~min},(\mathrm{e}) 10 \mathrm{~h}$, and (f) $20 \mathrm{~h}$ 


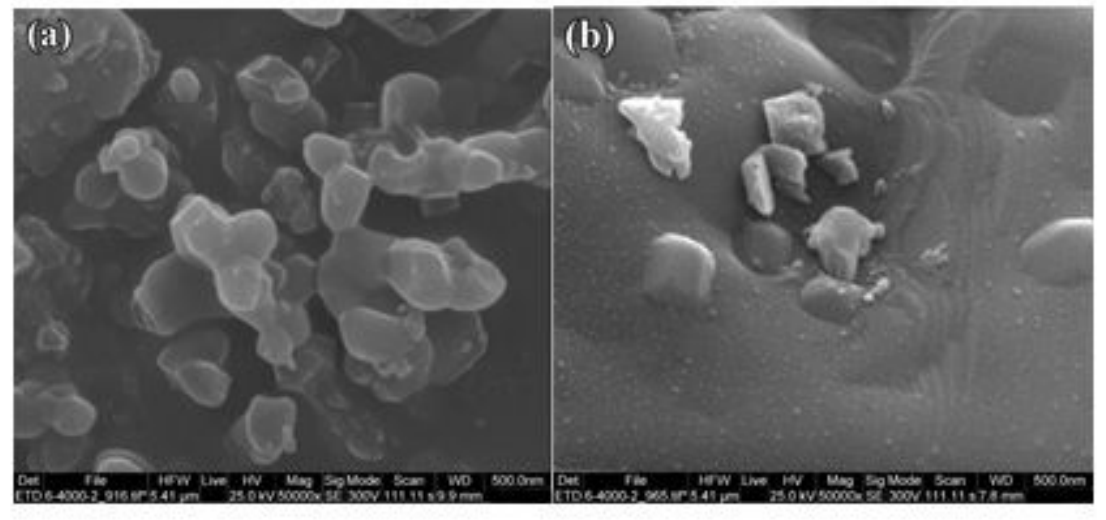

(c)

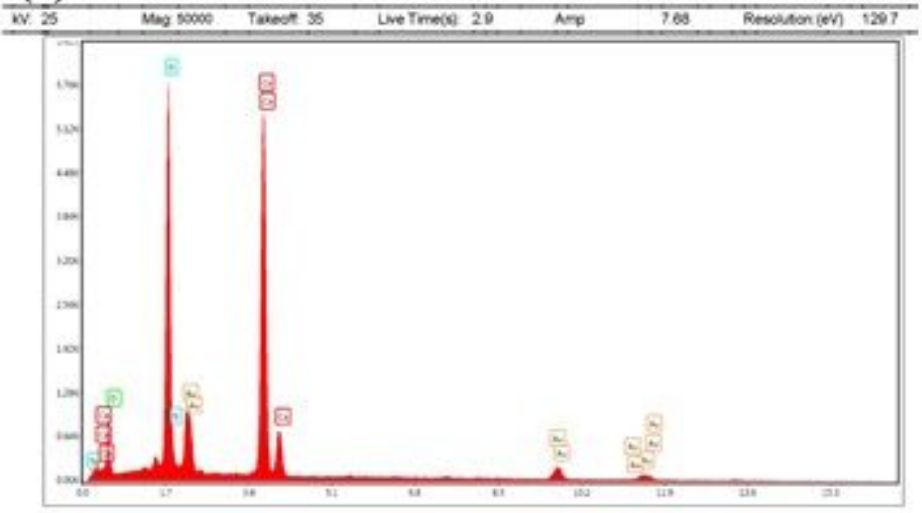

(d)

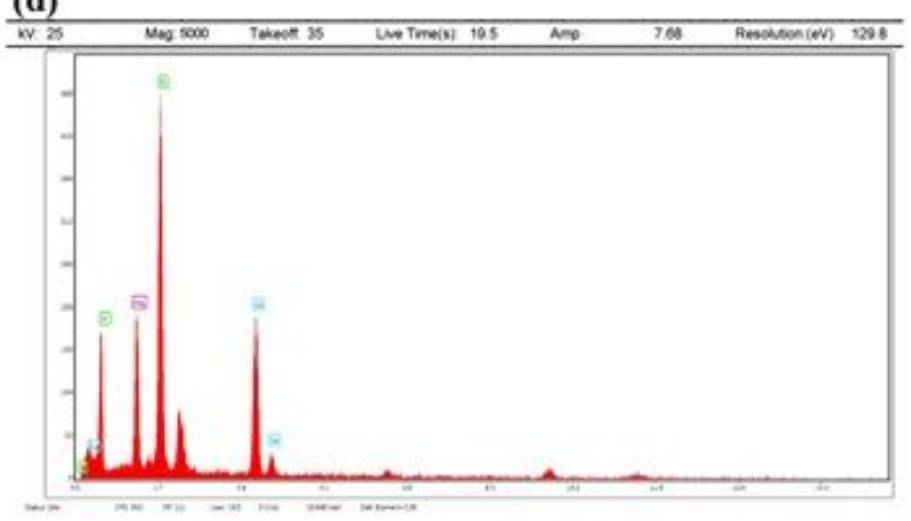

Figure 6

SEM images of (a) synthesized diopside and (b) synthesized wollastonite; (c) EDS analysis of synthesized diopside; (d) EDX analysis of the synthesized wollastonite 
(a)

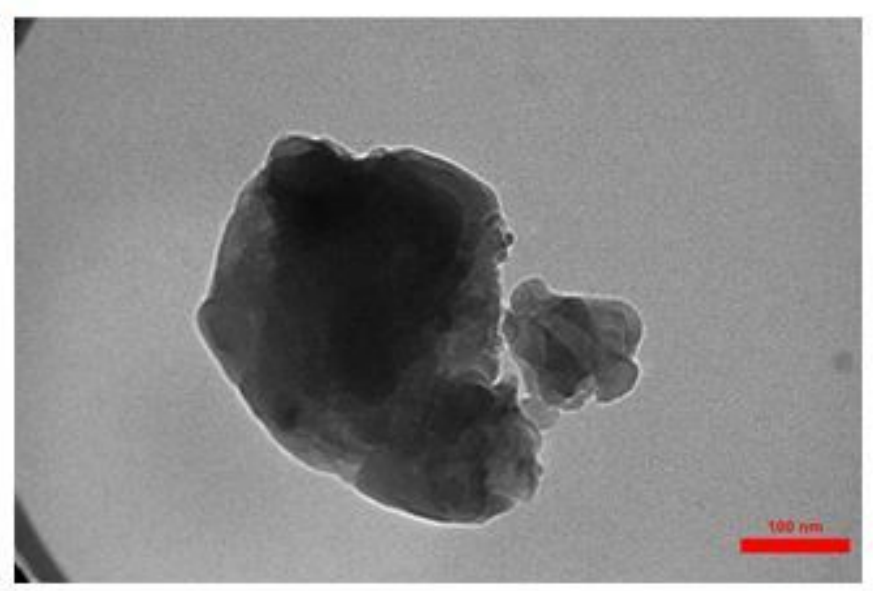

(b)

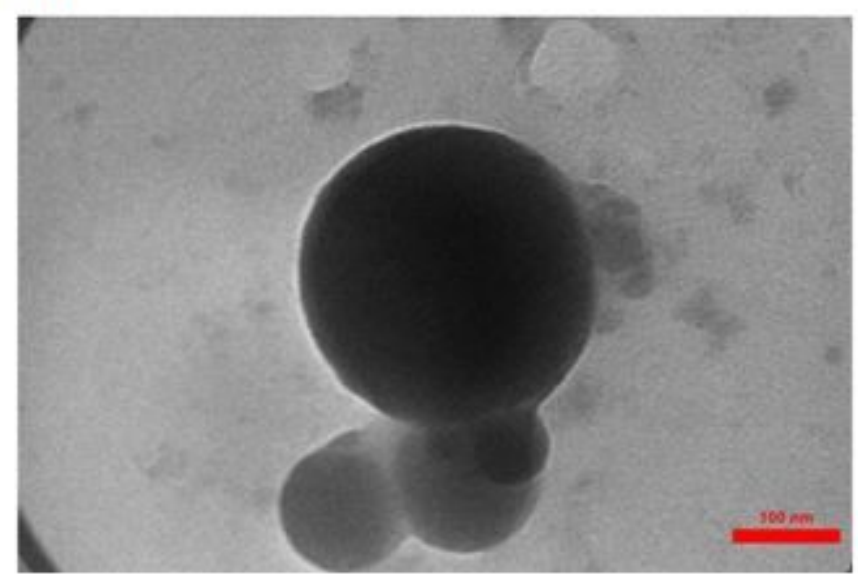

Figure 7

TEM images of (a) synthesized diopside and (b) synthesized wollastonite 
(a)

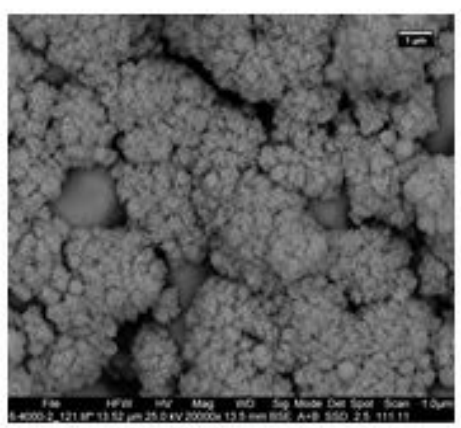

(b)

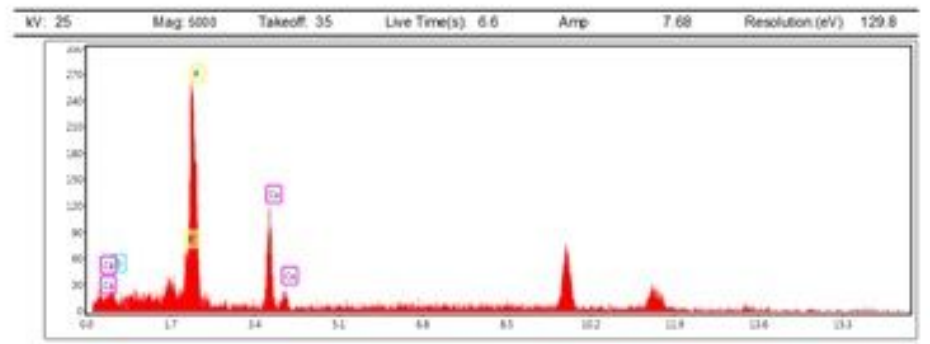

(c)

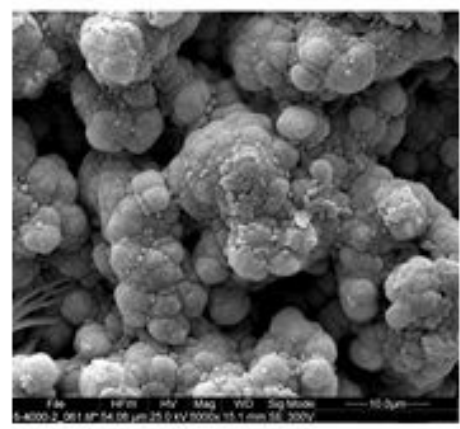

(d)

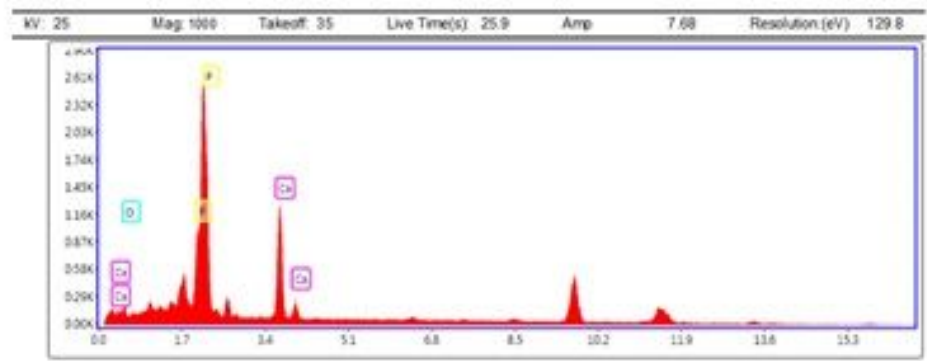

Figure 8

(a) SEM image of wollastonite in immersed SBF up to 28 days, (b) EDX analysis, (c) SEM image of diopside immersed in SBF up to 28 days, (d) EDX analysis

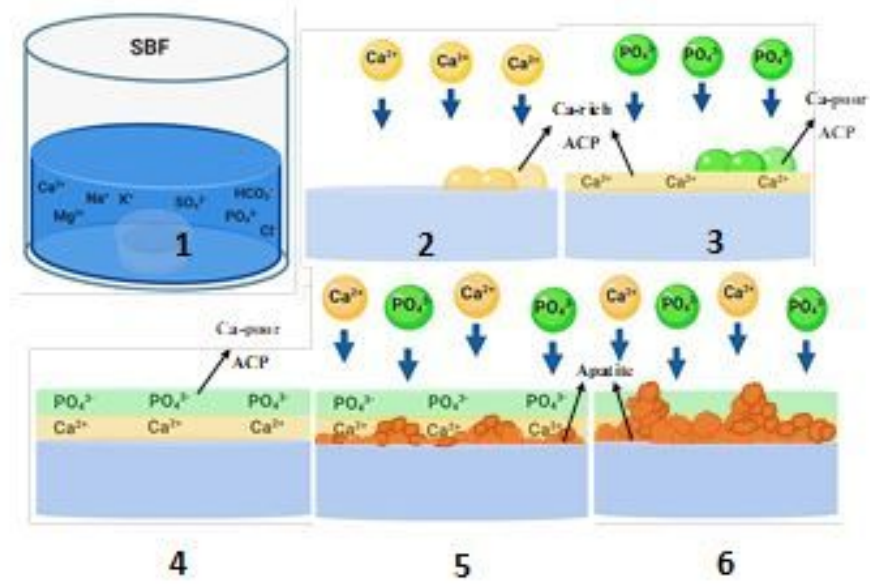

Figure 9

The mechanism of apatite formation on bioactive diopside and wollastonite nano-bioceramics 


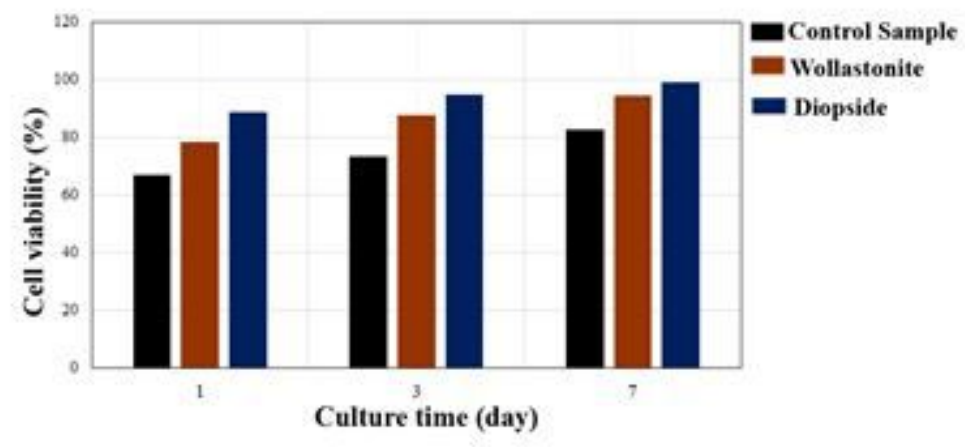

Figure 10

Results of cell viability related to wollastonite and diopside nano-bioceramics

(a)

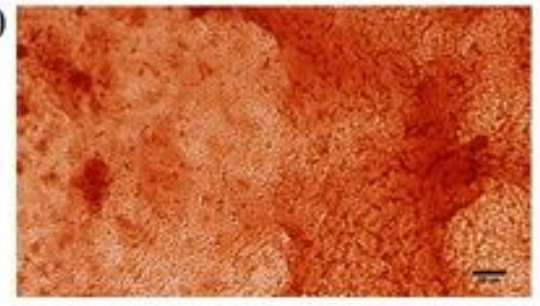

(b)

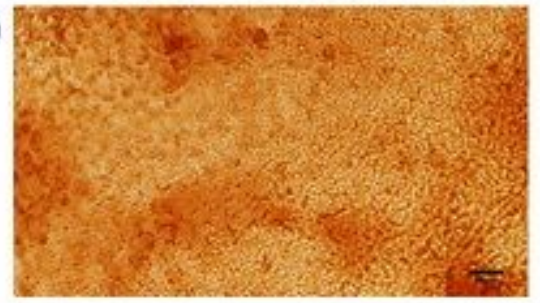

(c)

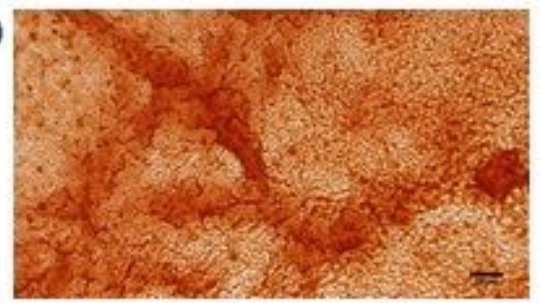

(d)

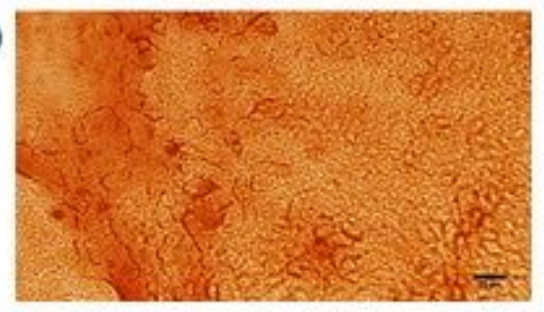

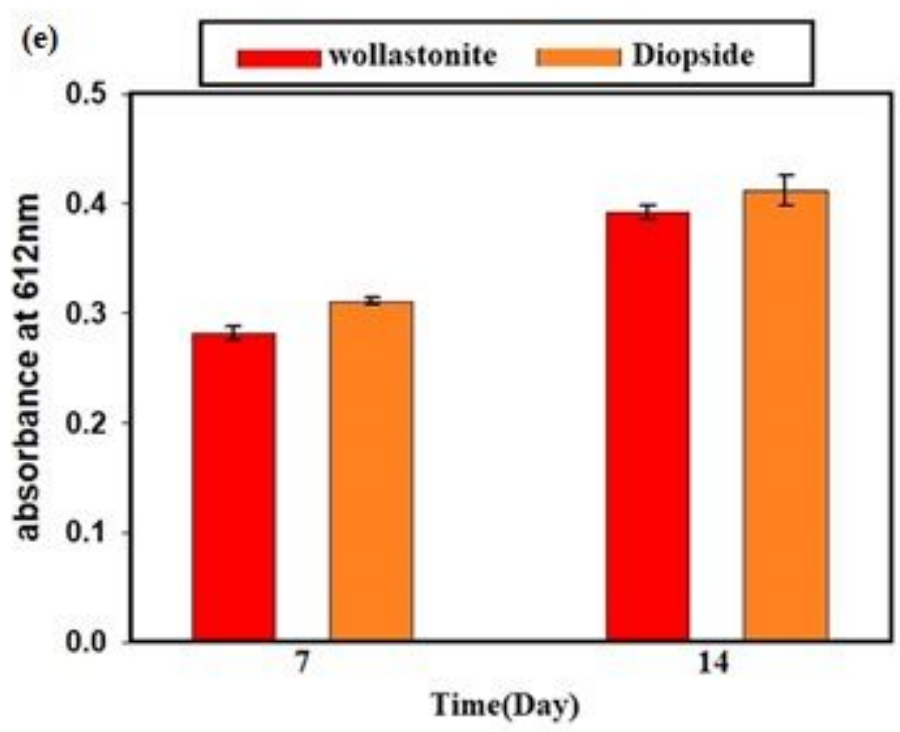

Figure 11

(a) and (b) Optical microscope images of the culture medium (MG - 63 osteoblast cells and diopside) obtained by alizarin red staining, (c) and (d) Optical microscope images of the culture medium (MG - 63 osteoblast cells and wollastonite) obtained by alizarin red staining, and diagram of optical absorption according to the culture time (day) after alizarin red staining relevant to diopside and wollastonite compounds, and (e) Optical density-culture time (day) diagram of alizarin red staining 


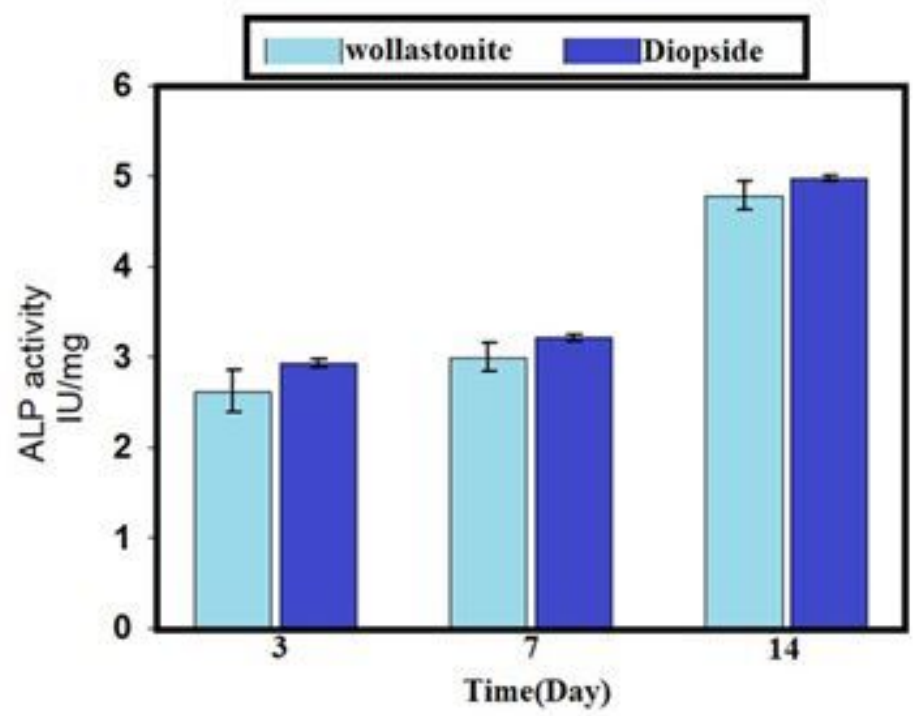

Figure 12

Diagram of ALP rate - culture time (day) after culturing for 3, 7 and 14 days related to diopside and wollastonite compounds 